\title{
Diterpenoids as potential anti-malarial compounds from Andrographis paniculata
}

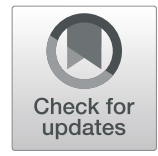

\author{
Manish Kumar Dwivedi, Shringika Mishra, Shruti Sonter and Prashant Kumar Singh*
}

\begin{abstract}
Background: The objectives of the current study are to evaluate the traditionally used medicinal plants Andrographis paniculata for in vitro anti-malarial activity against human malarial parasite Plasmodium falciparum and to further characterize the anti-malarial active extract of $A$. paniculata using spectroscopic and chromatographic methods.

Results: The chloroform extract of A. paniculata displayed anti-malarial activity with $\mathrm{IC}_{50}$ values $6.36 \mu \mathrm{g} / \mathrm{ml}$ against 3D7 strain and $5.24 \mu \mathrm{g} / \mathrm{ml}$ against $\mathrm{K} 1$ strains respectively with no evidence of significant cytotoxicity against mammalian cell line $\left(\mathrm{CC}_{50}>100 \mathrm{\mu g} / \mathrm{ml}\right)$. LC-MS analysis of the extract led to the identification of 59 compounds based on their chromatographic and mass spectrometric features (a total of 35 compounds are present in positive ion and 24 compounds in negative ion mode). We have identified 5 flavonoids and 30 compounds as diterpenoids in positive ion mode, while in the negative mode all identified compounds were diterpenoids. Characterization of the most promising class of compound diterpenoids using HPLC-LC-ESI-MS/MS was also undertaken.

Conclusions: The in vitro results undoubtedly validate the traditional use of $A$. paniculata for the treatment of malaria. The results have led to the identification of diterpenoids from IGNTU_06 extract as potential anti-malarial compounds that need to be further purified and analyzed in anti-malarial drug development programs.
\end{abstract}

Keywords: Andrographis panicualta, Diterpenoid, In vitro anti-malarial activity, Liquid chromatography, Traditional medicine

\section{Background}

Malaria, caused by Plasmodium spp., is a major cause of global mortality [1, 2]. Anti-malarial drugs like chloroquine, quinine, artemisinin, arteether, and their derivatives have been used as major drugs against this dreadful disease [3]. The emergence of resistance against currently used antimalarial drugs has become a critical problem for malaria control programs [4]. There is an urgent requirement for new anti-malarial drug development that is well-tolerated, affordable, and more efficient in tackling the global problem of drug resistance [5]. The majority of anti-malarial drugs like quinoline based drugs, artemisinin, and its derivatives have been derived from medicinal plants [4]. In malaria-endemic countries, traditional medicine can open new avenues for

\footnotetext{
* Correspondence: prashant.singh@igntu.ac.in

Department of Biotechnology, Indira Gandhi National Tribal University, Amarkantak, Madhya Pradesh 484887, India
}

novel molecules to be developed as anti-malarial drugs [1]. For the duration of the precedent 1-2 decades, the researcher budge spotlight from synthetic drugs to alternative plant-based drugs has occurred. Currently, isolated pure compounds from medicinal plants are extensively used in modern medicine; approximately 120 active compounds are presently used [6]. Among the major 100 plants, about 40 tropical plants account as the source of more than 120 pharmacologically active metabolites [7]. Apart from the pharmaceutical importance, these plants are being extensively utilized as herbal products for nutritional and medicinal purposes that help in disease prevention and health improvement [8]. We have earlier documented 19 plants being used by traditional medicinal healers that they use for treating malaria. Geographical Information System (GIS) maps of all 19 anti-malarial plants were also prepared $[9,10]$. Based on the maximum usage index, Andrographis 
paniculata was selected for carrying out in vitro anti-malarial assays $\left(\mathrm{IC}_{50}\right.$ values $6.79 \mu \mathrm{g} / \mathrm{ml}$ against $3 \mathrm{D} 7$ strain and $4.26 \mu \mathrm{g} / \mathrm{ml}$ against $\mathrm{K} 1$ strains), and we obtained promising results in the chloroform whole plant extract (unpublished results).

A. paniculata is a magnificent tropical traditional medicinal plant that belongs to the family Acanthacea and is usually well-known as "Kalmegh" or "King of Bitter" [11]. A. paniculata is an herb having erect branches growing up to 1-2 $\mathrm{m}$ in length. It is traditionally used for medicinal purpose in Hong Kong, Philippines, Taiwan, China, India, Malaysia, Indonesia, and many South Asian countries [12]. Medicinal properties of $A$. paniculata have also been highlighted by WHO in its 2002 monograph [13]. Humans are using medicinal plants in traditional medicine since ancient times for treating a wide variety of diseases. The extracts contain several small molecules that are structurally and functionally diverse in nature and are known as secondary metabolites or phytochemicals [14-16]. It is generally used to treat different diseases such as liver and bowel disorders, colic pain, influenza [17, 18], respiratory infections, rheumatism, hypertension, diabetes, and arthritis, and used as an analgesic, protozocidal, antioxidant, anti-HIV, immune-stimulant, antimicrobial, antipyretic, and anticancer $[12,19,20]$. A paniculata has been used for the treatment of dyspepsia, dysentery, snakebite, insect sting, influenza, and respiratory infections [19].

Several drugs have been obtained from natural products, and the synthesis of their derivatives has led to the improvement in drug-like properties of such molecules. The plant kingdom presents us with a diverse and large array of chemical compounds making it imperative to design reliable and rapid plant extract screening assays. Liquid chromatography (LC-MS) has emerged as a potent tool for the characterization and purification of phytoconstituents [21]. In light of these observations, this current study aims to validate the traditionally used medicinal plant $A$. paniculata for evaluating its in vitro anti-malarial potential. We have also developed a novel method to profile and identify phytochemicals from the potential antimalarial active whole plant extract by using HPLC-LCMS/MS. We have also identified active compounds present in chloroform extracts of A. paniculata by thinlayer chromatography, UV-Visible spectroscopy, FTIR, and HPLC. LC-MS method was developed to identify and characterize the major constituents (diterpenoids) present in the chloroform extract of $A$. paniculata. In the positive ion mode, the characterized diterpenoids were based on their retention time and MS spectra data.

\section{Methods}

\subsection{Chemicals and reagents}

Analytical grade (AR) or liquid chromatography (LC) grade chemicals and reagents were used in the study.
Methanol (AR and LC grade), acetonitrile (HPLC and LC grade), ammonium $\left(\mathrm{NH}_{4}\right)$, and chloroform (AR) were purchased from Central Drug House $(\mathrm{CDH}(\mathrm{P})$ Ltd.). Ultra-pure water was used in preparing all buffers and reagents (Millipore, USA).

\subsection{Extraction of crude extracts}

Based on the relative frequency of citation obtained from the field survey $A$. paniculata, whole plants were selected and dried (air) for 30 days in the shade at room temperature (RT) $\left(25-28^{\circ} \mathrm{C}\right)$. The dried plant $(500 \mathrm{~g})$ of A. paniculata was powdered mechanically using a steel blender. The powder samples were stored in airtight bottles used for the extraction process using a Soxhlet apparatus $\left(60-80^{\circ} \mathrm{C}\right)$ for $4-8 \mathrm{~h}$. Various extracts were prepared based on polar to non-polar solvents such as methanol, chloroform, n-hexane, and aqueous solvent. We classified plant extracts of $A$. paniculata as follows: IGNTU_05_methanol, IGNTU_06_chloroform, IGNTU_ 07_n-Hexane, and IGNTU_08_aquous. All the extracts were concentrated with the help of a rotary evaporator $\left(22-26 \mathrm{mmHg} ; 45-60^{\circ} \mathrm{C}\right)$. The concentrated residual extracts were weighed, and yield percentage was calculated for each and stored at $4{ }^{\circ} \mathrm{C}$ till further use.

\subsection{In vitro anti-malarial activity \\ 2.3.1 Culture of Plasmodium falciparum}

Evaluation of in vitro anti-malarial activity used plant extracts against chloroquine-sensitive strain 3D7 and multidrug-resistant $\mathrm{K} 1$ strain (resistant to chloroquine, sulfadoxine-pyrimethamine, chlorproguanil) of $P$. falciparum. Chloroquine sensitive (3D7) strain of P. falciparum is routinely cultured at CSIR-Central Drug Research Institute, Lucknow, India, following the method of Trager and Jensen [22] Culture of the parasite was maintained at $6-8 \%$ parasitemia and $2 \%$ hematocrit in complete RPMI medium (RPMI 1640 supplemented with D-glucose $(0.2 \%)$, HEPES, sodium bicarbonate (0.2\%), albumax (0.5\%), hypoxanthine $(45 \mathrm{mg} / \mathrm{l})$, fungizone $(0.25 \mathrm{mg} / \mathrm{l})$, and gentamycin $(50 \mathrm{mg} / \mathrm{l})$ at $37^{\circ} \mathrm{C}$ in a humidified $\mathrm{CO}_{2}$ incubator [23]. Stock solutions $5 \mathrm{mg} / \mathrm{ml}$ of extracts prepared in $100 \%$ di-methyl sulfoxide (DMSO) for IGNTU_05, IGNTU_08, in tetrahydrofolic acid (THF) for IGNTU_06, and in water for IGNTU_07. The extracts were diluted in RPMI-1640 culture medium. The malaria SYBR Green I-based fluorescence assay was carried out for evaluating $50 \%$ inhibitory concentration $\left(\mathrm{IC}_{50}\right)$ of the extracts tested [24].

\subsubsection{Evaluation of anti-malarial activity}

Chloroquine (C-6628, Sigma) was used as a standard drug, and stock concentration was prepared in water. Stock concentrations of plant extracts $(50 \mu \mathrm{g} / \mathrm{ml})$ were prepared in dimethyl sulphoxide (DMSO) or 
tetrahydrofuran (THF). Experiments for parasite inhibition were conducted at $0.8 \%$ parasitemia maintained at $1 \%$ hematocrit in complete RPMI medium. The highest concentration of test samples was $50 \mu \mathrm{g} / \mathrm{ml}$. Dual serial dilutions of test samples were prepared in triplicates in 96-well microtiter plates and were used for the treatment of the ring stage of the parasite. Untreated parasite (infected-RBCs) and non-infected RBCs were used positive and negative control, respectively. In parallel, parasite culture was maintained in $60 \mathrm{~mm}$ dish without any drug to monitor the parasite growth $\left(37^{\circ} \mathrm{C}, 72 \mathrm{~h}\right)$. After the $72 \mathrm{~h}, 100 \mu \mathrm{l}$ lysis buffer [20 mM Tris- $\mathrm{HCl}(\mathrm{pH} 7.5)$, saponin (0.008\%), and Triton X-100 (0.08\%), $5 \mathrm{mM}$ EDTA] containing $2 \times$ SYBR Green dye (S7585) was added to the individual well of the 96-well plate and incubated at $37^{\circ} \mathrm{C}$ for $1 \mathrm{~h}$. With excitation at $480 \mathrm{~nm}$ and emission at $520 \mathrm{~nm}$, the fluorescence was recorded (FLX800, BIOTEK instrument). Data was analyzed to obtain inhibitory concentration $\left(\mathrm{IC}_{50}\right)$ values for plant extracts. The extracts displaying $\mathrm{IC}_{50} \leq 10.0 \mu \mathrm{g} / \mathrm{ml}$ have promising anti-malarial activity.

\subsubsection{Determination of in vitro cytotoxic activity}

The MTT assay was performed for cytotoxicity evaluation in VERO cells (C1008, epithelial cells from monkey kidney). VERO cells were maintained in RPMI media supplemented with HEPES, $0.2 \%$ sodium bicarbonate, $0.2 \%$ D-glucose, $10 \% \mathrm{FBS}$, fungizone $(0.25 \mathrm{mg} / \mathrm{l})$, and gentamycin $(50 \mathrm{mg} / \mathrm{l})$ in a humidified $\mathrm{CO}_{2}$ incubator maintained at $37^{\circ} \mathrm{C}$. Cells $\left(10^{4}\right)$ were seeded in 96-well plates and treated with the test compounds in different dilutions $(16-18 \mathrm{~h}$ postseeding). Podophyllotoxin (P4405, Sigma) was used as the positive control. After $72 \mathrm{~h}$ of incubation, $25 \mu \mathrm{l}$ of MTT (M2128, Sigma) (stock $5 \mathrm{mg} / \mathrm{ml}$ ) dye was added to each well of the plate that was re-incubated in $\mathrm{CO}_{2}$ incubator for another $2 \mathrm{~h}$. Cell supernatant was removed carefully without disturbing the cells. DMSO $(150 \mu \mathrm{l})$ was added to each well for dissolving the purple precipitate. Absorbance was recorded at 540 $\mathrm{nm}$ (ELISA reader) and data was analyzed to determine $50 \%$ cytotoxic concentration $\left(\mathrm{CC}_{50}\right)$.

\subsection{Thin-layer chromatography (TLC)}

TLC was undertaken at room temperature (RT) and $60 \%$ relative humidity at lab conditions for analysis of the plant extracts. The solvent system chloroform: methanol (90:10) was used as the mobile phase. The TLC plates (Merck-silica gel $60 \mathrm{~F}_{254}$ ) were kept in the UV chamber $(254 \mathrm{~nm})$ for a few minutes to visualize various spots in the samples under analysis. The $\mathrm{Rf}$ values were calculated using standard formula.

\subsection{UV-Visible spectroscopy}

The plant extracts were scanned between the 200-800 $\mathrm{nm}$ wavelength ranges (Shimadzu, UV-1800 UV-VisSpectrophotometer). Chloroform (analytical grade) was used as a blank and the plant extract was prepared in methanol $0.10 \mathrm{mg} / \mathrm{ml}$ concentration.

\subsection{Fourier-transform infrared spectroscopic (FTIR) analysis}

The FTIR spectroscopic analysis was performed to identify the characteristic peaks and the functional groups present in A. paniculata whole plant chloroform extract (IGNTU_06) using Thermo scientific iD7 ATR Spectrophotometer system. The plant extract was diluted in chloroform before scanning the FTIR spectrum at 400$4000 \mathrm{~cm}^{-1}$. The analysis was performed in duplicate for the confirmation of the spectrum.

\subsection{High-performance liquid chromatography}

About $100 \mathrm{mg}$ of plant extract was taken separately into a round bottom flask with the addition of $50 \mathrm{ml}$ of methanol. After sonication in a water bath for $5 \mathrm{~min}$, the mixture was passed through a $0.45-\mu \mathrm{m}$ membrane filter. The C18 column was used for chromatographic separation C18 column $(250 \mathrm{~mm} \times 4.6 \times 5 \mu \mathrm{m})$ (Water-HPLC Model no. waters 2489 UV/Visible). Isocratic elution was carried out with $1 \mathrm{ml} / \mathrm{min}$ flow rate at $1600 \mathrm{psi}$ using mobile phase acetonitrile:water $(60: 40 \mathrm{v} / \mathrm{v})$. The plant extract separation was detected with a D2 lamp at 223 $\mathrm{nm}$ wavelength. Ten-microliter samples were injected, and run time was kept at $30 \mathrm{~min}$. Empower 3 software was used for integration, calibration, and analysis.

\subsection{Liquid chromatographic mass analysis}

Liquid chromatography (LC) analysis was undertaken using a Aqua C18, $150 \times 2.1,2.6 \mu \mathrm{m}$ column (Waters ACQUITY QSM -TQD\#QBB1152). Gradient elution (Gradient Table 1) was performed using solvent A: 95\% $\left(\mathrm{H}_{2} \mathrm{O}\right.$ : $\left.\mathrm{ACN}\right)$; solvent $\mathrm{B}$ : acetonitrile; solvent $\mathrm{C}$ : methanol; and solvent D: $5 \mathrm{mM} \mathrm{NH}_{4}$ in 95:5 $\left(\mathrm{H}_{2} \mathrm{O}: \mathrm{ACN}\right)$ at a constant flow rate of $0.250 \mathrm{ml} / \mathrm{min}$ with flow ramp rate of $0.45 \mathrm{~min}$. Column temperature was set to $30^{\circ} \mathrm{C}$ at run time of $40 \mathrm{~min}$. The sample volume injected was set at $1 \mu \mathrm{l}$ and the high-pressure limit was set at 15,000 psi. Both positive and negative ion modes (+Ve and $-\mathrm{Ve}$ ) were used for acquiring the MS spectra using electrospray ionization (ESI) source. For the MS analysis, capillary voltage was kept to $3.50 \mathrm{kV}$ in $+\mathrm{Ve}$ and $-\mathrm{Ve}$ ion modes, collision gas flow was $0.23 \mathrm{ml} / \mathrm{min}$ in $+\mathrm{Ve}$ ion mode and $0.10 \mathrm{ml} / \mathrm{min}$ in $-\mathrm{Ve}$ ion mode, while the source temperature was $120^{\circ} \mathrm{C}$ for both modes. The ion energy I (0.50) and energy II (3.0) were used for positive and negative ion modes while the mass range 100 to $1000 \mathrm{~m} / \mathrm{z}$ was used for both ion modes. The instrument 
Table 1 Yield analysis, anti-malarial, and cytotoxic activities of Andrographis paniculata whole plant extracts

\begin{tabular}{|c|c|c|c|c|c|c|c|c|}
\hline \multirow[t]{2}{*}{ S. No. } & \multirow[t]{2}{*}{ Plants } & \multirow[t]{2}{*}{ Extract code } & \multirow[t]{2}{*}{ Parts used } & \multirow[t]{2}{*}{ Solvent } & \multirow[t]{2}{*}{ Yield $(\% \mathrm{w} / \mathrm{w})(\mathrm{W} 1 \times 100 / \mathrm{W} 2)^{*}$} & \multicolumn{2}{|c|}{$\begin{array}{l}\mathrm{I} \mathrm{I}_{50}(\mu \mathrm{g} / \mathrm{ml}) \\
\text { against }\end{array}$} & \multirow[t]{2}{*}{$\mathrm{CC}_{50}(\mu \mathrm{g} / \mathrm{ml}$} \\
\hline & & & & & & $3 \mathrm{D7}$ & K1 & \\
\hline 1 & Andrographis paniculata & IGNTU_05 & Whole plants & Methanol & 4.85 & 10.75 & 10.64 & 63.03 \\
\hline 2 & & IGNTU_06 & Whole plants & Chloroform & 7.01 & 6.36 & 5.24 & $>100$ \\
\hline 3 & & IGNTU_07 & Whole plants & n-Hexane & 6.97 & $>50$ & $>50$ & $>100$ \\
\hline 4 & & IGNTU_08 & Whole plants & Distil water & 4.11 & 9.35 & 10.87 & $>100$ \\
\hline Ref. drug & CQ-diphosphate* & & & & & 0.005 & $0.259 ; 0.251$ & 0.005 \\
\hline Ref. drug & Podophyllotoxin* & & & & & na & na & 3.13 \\
\hline
\end{tabular}

Parasite inhibition experiment was performed in 3D7 and K1 strains and cytotoxicity experiment was performed in VERO cells. IC ${ }_{50}$ and $\mathrm{CC}_{50}$ are the half-maximal inhibitory and cytotoxic concentrations, respectively. $\mathrm{IC}_{50}$ and $\mathrm{CC}_{50}$ values were determined $72 \mathrm{~h}$ after treatment of plant extract. Chloroquine (CQ), a 4aminoquinoline derivative, was used as a reference compound in the parasite inhibition assay. IC $\mathrm{C}_{50}$ obtained in PF3D7 and K1 was $5 \mathrm{nM}$ and $255 \mathrm{nM}$, respectively. For cytotoxicity evaluation, podophyllotoxin was used as a reference compound. $\mathrm{CC}_{50}$ obtained for podophyllotoxin was $3.13 \mu \mathrm{M}$. Selectivity index is a ratio of $\mathrm{CC}_{50} / \mathrm{IC}_{50}$ and found IGNTU_06 exhibits most promising anti-malarial activity and minimal cytotoxicity

* $\mathrm{W} 1=$ is the weight of the extract residue obtained after solvent removal

*W2 = is the weight of the plant parts in powder form taken

was externally calibrated daily for achieving acceptable accuracy with a bunch threshold of 0.1459 before sample analysis.

\subsection{Mass spectrometric conditions}

Positive electrospray ionization (ESI) mode was used for operating the mass spectrometer and recording the spectra in the mass range from 50 to $355 \mathrm{~m} / z$ for daughters of 333,50 to $375 \mathrm{~m} / z$ for daughters of 351,50 to $505 \mathrm{~m} /$ $z$ for daughters of 481 , and 50 to $690 \mathrm{~m} / z$ for daughters of 665 used for MS/MS. Collision energy was set at 25 $\mathrm{eV}$ for both masses. The accurate mass data of the molecular ions $(\mathrm{M}+1)$ and MS/MS product ions was processed using the Software Version: 1.50.1481 (Waters technology).

\subsection{Statistical analysis}

All the data analysis was done using Microsoft Excel. The inhibitory concentration values $\left(\mathrm{IC}_{50}\right)$ of the plant extracts were obtained by transferring the data into an Excel graphical program and expressed as a percentage of the untreated controls and then evaluated by Logit regression analysis using a preprogrammed Excel spreadsheet.

\section{Results}

\subsection{Yield calculation and in vitro anti-malarial activity}

Plant extracts were analyzed for yield namely IGNTU $06(7.01 \% \mathrm{w} / \mathrm{w})$, IGNTU_07 $(6.97 \% \mathrm{w} / \mathrm{w})$, IGNTU_05 $(4.85 \% \mathrm{w} / \mathrm{w})$, and IGNTU_08 $(4.11 \% \mathrm{w} / \mathrm{w})$, respectively. In the chloroform extracts, the highest yield was observed, and in aqueous extracts, the lowest yield was observed (Table 1). To validate the use of traditional plants by tribal communities against malaria, different plant extracts were in vitro evaluated for anti-malarial potential against both drug-sensitive and resistant strains of $P$. falciparum. We observed that plant extracts exhibited wide spectrum parasite inhibition concentration $\left(\mathrm{IC}_{50}\right)$ values. In chloroquine-sensitive strain, promising anti-malarial activities $\left(\mathrm{IC}_{50}\right)$ were observed in IGNTU_06 $(6.79 \mu \mathrm{g} /$ $\mathrm{ml})$, IGNTU_08 $(9.35 \mu \mathrm{g} / \mathrm{ml})$, and IGNTU_ $05(9.85 \mu \mathrm{g} /$ ml) extracts, while IGNTU_07 had poor anti-malarial activity respectively. Similar inhibitory concentrations were obtained in multidrug-resistant $\mathrm{K} 1$ strain (resistant to chloroquine, sulfadoxine-pyrimethamine, chlorproguanil). Further, these plant extracts were tested for their cytotoxic effects $\left(\mathrm{CC}_{50}\right)$ in VERO cells, and these plant extracts had variable $\mathrm{CC}_{50}$ values. Comparison of $\mathrm{IC}_{50}$ and $\mathrm{CC}_{50}$ values suggests that these plant extracts specifically inhibit parasite growth and have a minimal toxic effect on mammalian cells. Out of the tested extracts, IGNTU_06 showed the most promising anti-malarial activities against both drug-sensitive and resistant strains (Fig. 1 and Table 1). It would be interesting to further identify the bioactive scaffolds in these extracts and perform a comprehensive SAR to identify the potential lead molecule.

\subsection{TLC and UV-Visible spectroscopy}

The TLC analysis of chloroform extract of $A$. paniculata revealed the presence of five spots in the visible region having Rf values of $0.55,0.64,0.78,0.82$, and 0.92 , and in the UV region with $\mathrm{Rf}$ values of $0.44,0.55,0.64,0.78$, 0.82, and 0.92 (Fig. 2a, b) when a mobile phase of chloroform: methanol (90:10) was used. These Rf values when compared with the available literature data suggested them to be related with that of the diterpenoids.

The qualitative UV-Visible spectrum of chloroform extract of $A$. paniculata was scanned at 200 to $800 \mathrm{~nm}$ wavelength range to achieve peak sharpness and proper baseline. The spectrum peaks displayed seven bands at 235, 416, 458, 540, and $667 \mathrm{~nm}$ (Fig. 2c) with absorption values of $4.000,3.212,2.307,0.303$, and 1.469, respectively. 

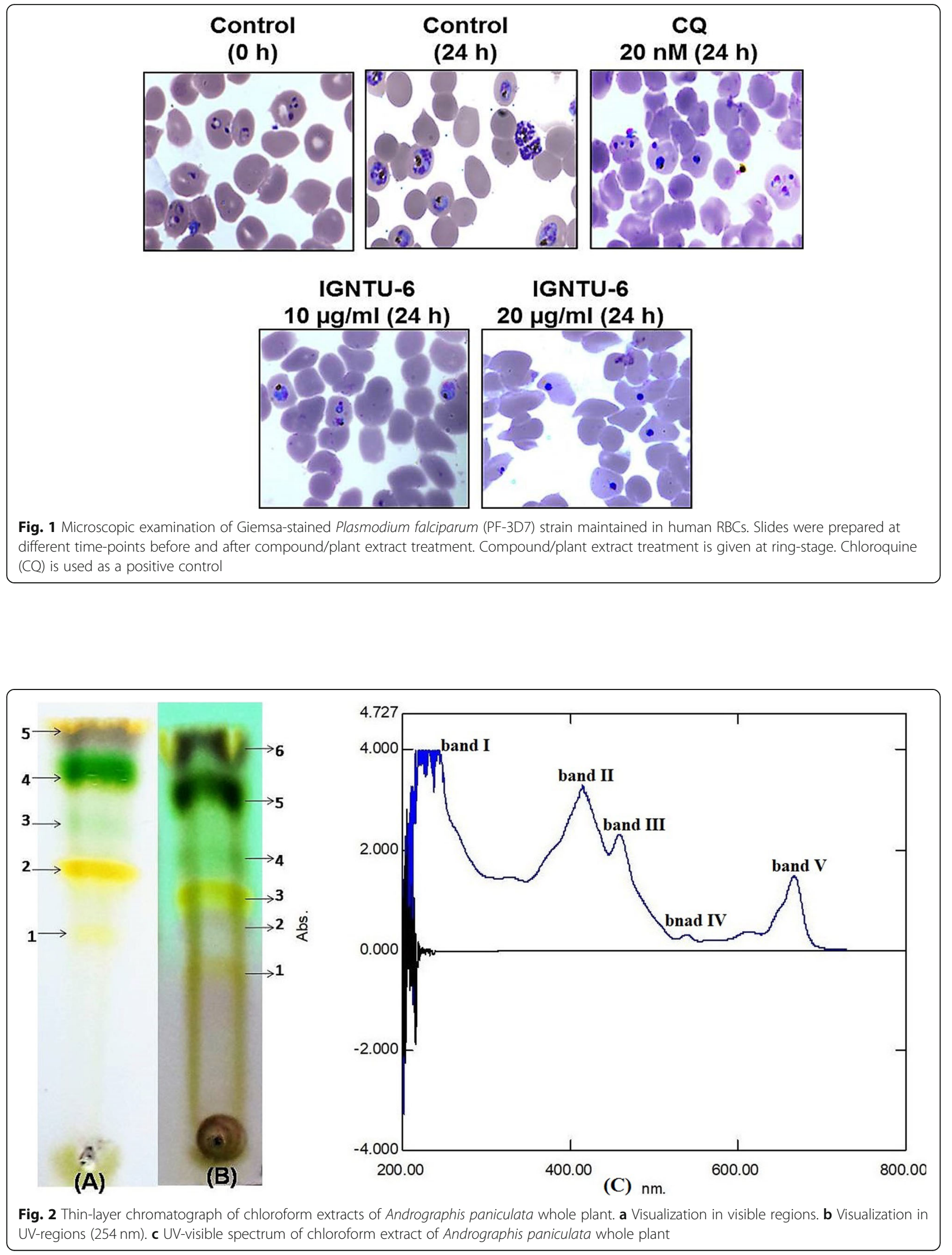


\subsection{FTIR analysis}

The FTIR spectrum was recorded for the identification of the major functional groups present in the active compounds based on the peak value observed in the infrared region. The observed peak values and functional groups are listed in Table 2 and Fig. 3. The spectrum displayed major peaks at 3350.1168, $3079.7370, \quad 2917.4682, \quad 2848.9200, \quad 1738.9023$, $1643.9741, \quad 1616.5713, \quad 1497.4885, \quad 1450.7719$, 1376.2922, $1346.5665, \quad 1214.3886, \quad 1162.4174$, 1077.3798, 1033.4677, 892.8850, 828.7537, 754.9412, and $719.7369 \mathrm{~cm}^{-1}$, respectively (Fig. 3).

\subsection{HPLC analysis}

The HPLC chromatogram of extract depicted nine compounds with different retention times using solvent system acetonitrile:water $(60: 40 \mathrm{v} / \mathrm{v})$. The peaks which could be identified in the chromatogram were unknown $(2.543,2.39 \%)$, unknown (3.101, 3.32), unknown $(3.760,7.82)$, unknown (4.761, 23\%), andrographolide (5.922, 49.50\%), unknown (7.081, 2.06\%), unknown (10.040, 1.11\%), neoandrographolide $(13.678,9.05 \%)$, and unknown (18.532, 1.76\%) (Fig. 4).

\subsection{LC-MS analysis of active compounds}

We were able to identify a total of 59 compounds and based on chemical skeleton majority of which belonged to the diterpenoids class and a few were flavonoids.

\subsubsection{Identification of diterpenoids}

Diterpenoids were analyzed in both $+\mathrm{Ve}$ and $-\mathrm{Ve}$ ion modes, and thus, the method was optimized for both ionization modes. A total of nineteen diterpenoids were detected in the positive ion mode, the base peak chromatogram is shown in Fig. 5a, and compounds are displayed in Table 3. Similarly, sixteen diterpenes were detected in negative ion mode along with an analysis of their structures. The base peak chromatogram of negative ion mode is shown in Fig. $5 \mathrm{~b}$ and Table 3. The chemical structure of diterpenoids is displayed in Fig. 10.

\subsubsection{Identification of flavones}

The base peak chromatogram in positive ionization mode of the active extract (IGNTU_06) is represented in Fig. 5a. Based on MS data, five flavones were detected in positive ion mode while not a single compound was present in negative ion mode (Fig. $5 \mathrm{~b}$ and Table 3 ).

Table 2 FTIR analysis of anti-malarial active extract of Andrographis paniculata

\begin{tabular}{|c|c|c|c|}
\hline Wavenumber $\left(\mathrm{Cm}^{-1}\right)$ & Functional group & Class/bond & Intensity \\
\hline 3436.0894 & $-\mathrm{OH}-$ broad & Hydroxyl & Medium \\
\hline 3079.7370 & $-\mathrm{C}-\mathrm{H}-$ stretch & Aromatic & Strong \\
\hline 2917.4682 & $-\mathrm{CH}-$ stretch & Alkanes & Strong \\
\hline 2848.9200 & $-\mathrm{CH} 2-$ & Alkanes & Medium \\
\hline 1738.9023 & $-\mathrm{C}=\mathrm{O}-$ stretch & Esters & Strong \\
\hline 1643.9741 & $-\mathrm{C}=\mathrm{C}-$ stretch (3-ring structure) & Alkanes & Weak \\
\hline 1616.5713 & $-C=C-$ stretch (5-ring structure) & Alkanes & Weak \\
\hline 1497.4885 & -C-C- stretch & Aromatic & Weak \\
\hline 1450.7719 & $-\mathrm{CH}_{2}$ and $\mathrm{CH}_{3}-$ & Alkanes & Medium \\
\hline 1376.2922 & $-\mathrm{CH} 3-$ & Alkanes & Weak \\
\hline 1346.5665 & N-O-Aromatic Nitro. & Aromatic Nitro & Weak \\
\hline 1214.3886 & $-\mathrm{C}-\mathrm{N}-$ stretch & Amines & Weak \\
\hline 1162.4174 & $-\mathrm{P}-\mathrm{H}-$ bending & Phosphine & Weak \\
\hline 1077.3798 & $-\mathrm{C}-\mathrm{O}-$ stretch & Ethers & Weak \\
\hline 1033.4677 & $\mathrm{C}-\mathrm{N}-$ stretch & Amines & Medium \\
\hline 892.8850 & $=\mathrm{C}-\mathrm{H}$-out of plane & Alkanes & Medium \\
\hline 828.7537 & -C-H-out of plane & Aromatic & Medium \\
\hline 754.9412 & $-\mathrm{S}-\mathrm{OR}-$ & Esters & Strong \\
\hline 719.7369 & $-\mathrm{C}-\mathrm{H}$-out of plane (trans $\mathrm{RCH}=\mathrm{CHR}$ ) & Aromatic & Weak \\
\hline
\end{tabular}




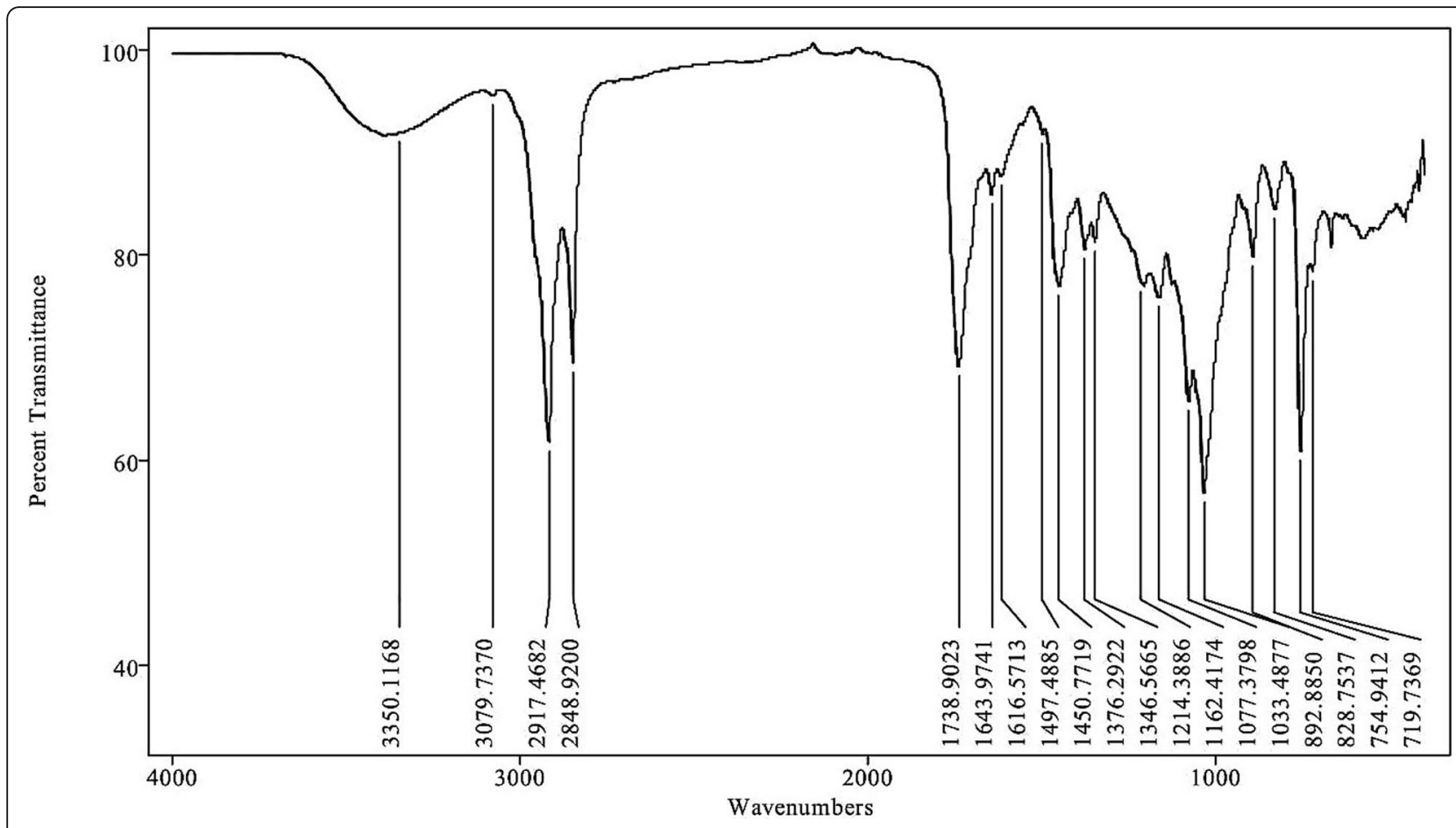

Fig. 3 FTIR spectrum of chloroform extract of Andrographis paniculata whole plant

\subsection{MS/MS characterization of diterpenoids}

Both low and high molecular weight molecules from plant extracts can effectively be characterized structurally using LC-MS/MS. IGNTU_06 was found to contain 41 compounds with a maximum number of diterpenoids (36 compounds). To authenticate the current findings, we carried out MS/MS analysis of four different molecules with different chemical skeleton and mass. The fragmentation pathways and diagnostic product ions of andrographolide, neoandrographolide, and bisandrographolide $\mathrm{A}$ and 14deoxy-11,12-didehydroandrographolide were studied by LC-ESI-MS/MS spectra of the $(\mathrm{M}+\mathrm{H})^{+}$ions as shown in Figs. 6, 7, 8, and 9.

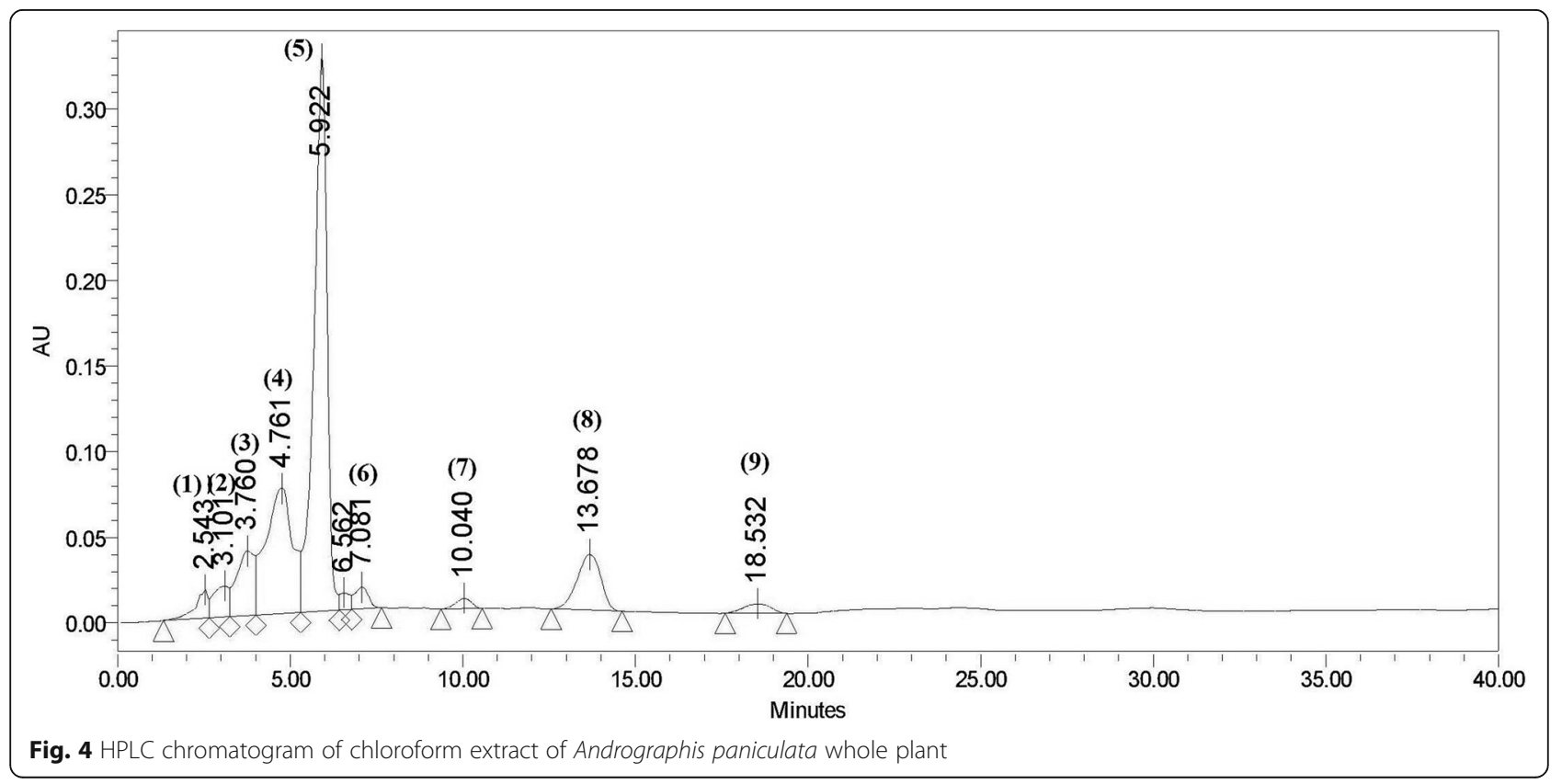




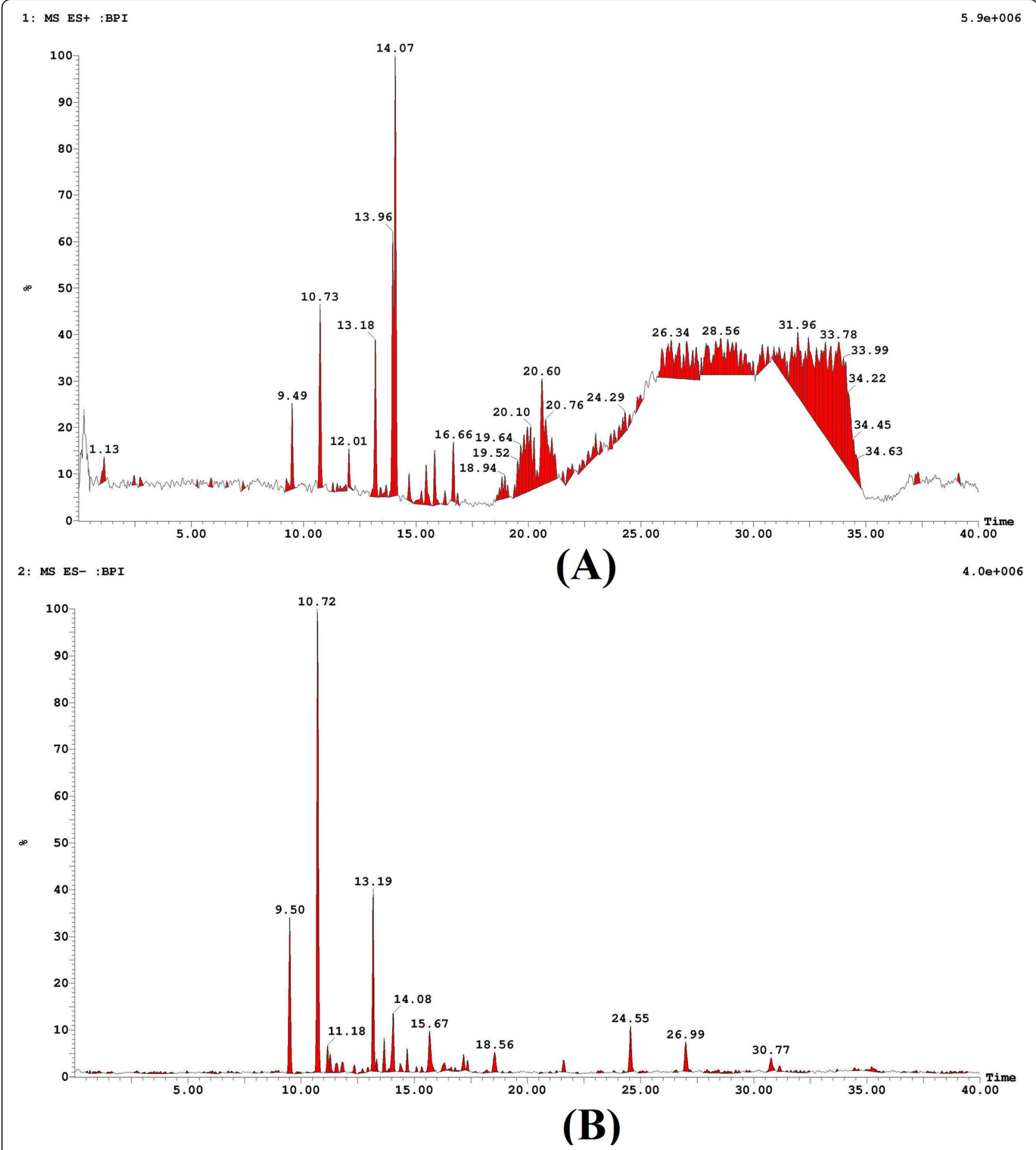

Fig. 5 Basic peak chromatogram of chloroform extract of Andrographis paniculata whole plant. a Positive ion mode. b Negative ion mode

The MS/MS spectrum and fragmentation pathways of 14-deoxy-11, 12-didehydroandrographolide ([M+ $\mathrm{H}]+$ ion detected at $\mathrm{m} / \mathrm{z} 333$ ) are shown in Fig. 6 . The MS/MS spectrum showed product ion at $\mathrm{m} / \mathrm{z}$ 197and 183 due to loss of $\mathrm{C}_{9} \mathrm{H}_{12} \mathrm{O}$ from $333 \mathrm{~m} / z$ and $\mathrm{CH}_{2}$ (demethylation) from $197 \mathrm{~m} / z$. Product ions at 169 and $133 \mathrm{~m} / \mathrm{z}$ were observed due to fragmentation of $\mathrm{CH}_{2}$ (demethylation) and $2 \mathrm{H}_{2} \mathrm{O}$ (hydrolysis) from 183 and $169 \mathrm{~m} / z$, respectively. Similarly, ions at 119 and $105 \mathrm{~m} / z$ were formed due to loss of $\mathrm{CH}_{2}$ (demethylation) from 133 and $119 \mathrm{~m} / z$ in that order. The ions at 91 and $77 \mathrm{~m} / z$ were produced by consecutive loss of $\mathrm{CH}_{2}$ (demethylation) from 105 and $91 \mathrm{~m} / \mathrm{z}$. 
Table 3 Identification of compounds present in anti-malarial active extract of Andrographis paniculata by LC-MS/MS analysis

\begin{tabular}{|c|c|c|c|c|c|}
\hline $\begin{array}{l}\text { Peak } \\
\text { No. }\end{array}$ & $\begin{array}{l}\text { RT } \\
\text { (Min) }\end{array}$ & $\begin{array}{l}\text { Molecular weight } \\
(\mathrm{g} / \mathrm{mol})\end{array}$ & Molecular formula & $\begin{array}{l}\text { Class of identified } \\
\text { compounds }\end{array}$ & $\begin{array}{l}\text { LC-MS (obtained } \\
\text { mass, } m / z \text { ) }\end{array}$ \\
\hline \multicolumn{6}{|c|}{ Positive mode (ES+) } \\
\hline 1 & 6.58 & 480.598 & Neoandrographolide $\left(\mathrm{C}_{26} \mathrm{H}_{40} \mathrm{O}_{8}\right)$ & Diterpenoid & $481.6(M+1)$ \\
\hline 2 & 9.49 & 350.455 & Andrographolide $\left(\mathrm{C}_{20} \mathrm{H}_{30} \mathrm{O}_{5}\right)$ & Diterpenoid & $351.3(\mathrm{M}+1)$ \\
\hline 3 & 10.73 & 350.455 & Andrographolide $\left(\mathrm{C}_{20} \mathrm{H}_{30} \mathrm{O}_{5}\right)$ & Diterpenoid & $701.5(2 \mathrm{M}+1)$ \\
\hline 4 & 11.29 & 368.46 & 12S-Hydroxyandrographolide $\left(\mathrm{C}_{20} \mathrm{H}_{32} \mathrm{O}_{6} \mathrm{Na}\right)$ & Diterpenoid & $451.2(\mathrm{M}+1+2 \mathrm{ACN})$ \\
\hline 5 & 11.50 & 332.44 & 14-Deoxy-11,12-didehydroandrographolide $\left(\mathrm{C}_{20} \mathrm{H}_{28} \mathrm{O}_{4}\right)$ & Diterpenoid & $333.5(M+1)$ \\
\hline 6 & 11.62 & 484.6 & $\begin{array}{l}\text { Ent-Labda-8(17), 13Z-diene-15, 16, 19-triol 19-O-glucoside } \\
\left(\mathrm{C}_{26} \mathrm{H}_{44} \mathrm{O}_{8}\right)\end{array}$ & Diterpenoid & $485.3(M+1)$ \\
\hline 7 & 12.01 & 300.266 & 5,8,2'-Trihydroxy-7-methoxyflavone $\left(\mathrm{C}_{16} \mathrm{H}_{12} \mathrm{O}_{6}\right)$ & Flavone & $301.1(M+1)$ \\
\hline 8 & 13.18 & 318.457 & Andrograpanin $\left(\mathrm{C}_{20} \mathrm{H}_{30} \mathrm{O}_{3}\right)$ & Diterpene & $319.2(M+1)$ \\
\hline 9 & 13.18 & 497.60 & Andrographatoside $\left(\mathrm{C}_{26} \mathrm{H}_{42} \mathrm{O}_{9}\right)$ & Diterpenoid & $498.3(M+1)$ \\
\hline 10 & 13.66 & 522.63 & 6-acetylneoandrographolide $\left(\mathrm{C}_{28} \mathrm{H}_{42} \mathrm{O}_{9}\right)$ & Diterpenoid & $523.3(M+1)$ \\
\hline 11 & 13.67 & 520.482 & $\begin{array}{l}\text { 5-Hydroxy-7,8,2',5'- tetra- Methoxyflavone 5-O-glucoside } \\
\left(\mathrm{C}_{25} \mathrm{H}_{28} \mathrm{O}_{12}\right)\end{array}$ & Flavone & $584.3(\mathrm{M}+\mathrm{Na}+\mathrm{ACN})$ \\
\hline 12 & 13.96 & 334.456 & 14-Deoxyandrographiside $\left(\mathrm{C}_{20} \mathrm{H}_{30} \mathrm{O}_{4}\right)$ & Diterpenoid & $691.5(2 \mathrm{M}+\mathrm{Na})$ \\
\hline 13 & 14.07 & 664.88 & Bisandrographolide $\mathrm{A}\left(\mathrm{C}_{40} \mathrm{H}_{56} \mathrm{O}_{8}\right)$ & Diterpenoid & $687.5(\mathrm{M}+\mathrm{Na})$ \\
\hline 14 & 14.07 & 350.455 & Andrographolide $\left(\mathrm{C}_{20} \mathrm{H}_{30} \mathrm{O}_{5}\right)$ & Diterpenoid & $433.1(\mathrm{M}+1+2 \mathrm{ACN})$ \\
\hline 15 & 14.69 & 314.3 & Skullcapflavone I $\left(\mathrm{C}_{17} \mathrm{H}_{14} \mathrm{O}_{6}\right)$ & Flavone & $315.2(M+1)$ \\
\hline 16 & 15.23 & 296.41 & Andrographolactone $\left(\mathrm{C}_{20} \mathrm{H}_{24} \mathrm{O}_{2}\right)$ & Diterpenoid & $297.2(M+1)$ \\
\hline 17 & 15.44 & 352.42 & 7-Hydroxy-14-deoxyandrographolide $\left(\mathrm{C}_{19} \mathrm{H}_{28} \mathrm{O}_{6}\right)$ & Diterpenoid & $353.4(M+1)$ \\
\hline 18 & 15.44 & 664.88 & Bisandrographolide $\mathrm{A}\left(\mathrm{C}_{40} \mathrm{H}_{56} \mathrm{O}_{8}\right)$ & Diterpenoid & $665.5(M+1)$ \\
\hline 19 & 15.83 & 318.457 & Andrograpanin $\left(\mathrm{C}_{20} \mathrm{H}_{30} \mathrm{O}_{3}\right)$ & Diterpenoid & $659.6(2 \mathrm{M}+\mathrm{Na})$ \\
\hline 20 & 16.66 & 358.346 & 5-hydroxy-7,8,2',5'tetramethoxyflavone glucoside $\left(\mathrm{C}_{19} \mathrm{H}_{18} \mathrm{O}_{7}\right)$ & Flavone & $359.2(M+1)$ \\
\hline 21 & 18.71 & 664.88 & Bisandrographolide $\mathrm{A}\left(\mathrm{C}_{40} \mathrm{H}_{56} \mathrm{O}_{8}\right)$ & Diterpenoid & $665.5(M+1)$ \\
\hline 22 & 18.82 & 298.29 & 7-O-Methylwogonin $\left(\mathrm{C}_{17} \mathrm{H}_{14} \mathrm{O}_{5}\right)$ & Flavone & $623.5(2 \mathrm{M}+\mathrm{Na})$ \\
\hline 23 & 19.06 & 532.586 & 3-Oxo-14-deoxy-11,12-Didehydroandrographolide $\left(\mathrm{C}_{28} \mathrm{H}_{36} \mathrm{O}_{10}\right)$ & Diterpenoid & $533.5(M+1)$ \\
\hline 24 & 19.79 & 664.88 & Bisandrographolide $\mathrm{A}\left(\mathrm{C}_{40} \mathrm{H}_{56} \mathrm{O}_{8}\right)$ & Diterpenoid & $687.5(\mathrm{M}+\mathrm{Na})$ \\
\hline 25 & 20.25 & 512.596 & Andrographiside $\left(\mathrm{C}_{26} \mathrm{H}_{40} \mathrm{O}_{10}\right)$ & Diterpenoid & $513.4(M+1)$ \\
\hline 26 & 20.60 & 350.455 & Andrographolide $\left(\mathrm{C}_{20} \mathrm{H}_{30} \mathrm{O}_{5}\right)$ & Diterpenoid & $723.5(2 \mathrm{M}+\mathrm{Na})$ \\
\hline 27 & 20.76 & 611.70 & $\begin{array}{l}\text { 19-O-[ } \beta \text {-D-Apiofuranosyl(1f2)- } \beta \text {-D-glucopyranoyl]-3,14- } \\
\text { dideoxyandrographolide }\left(\mathrm{C}_{31} \mathrm{H}_{47} \mathrm{O}_{12}\right)\end{array}$ & Diterpenoid & $634.5(\mathrm{M}+\mathrm{Na})$ \\
\hline 28 & 21.03 & 611.70 & $\begin{array}{l}\text { 19-O-[3-D-Apiofuranosyl(1f2)- } \beta \text {-D-glucopyranoyl]-3,14- } \\
\text { dideoxyandrographolide }\left(\mathrm{C}_{31} \mathrm{H}_{47} \mathrm{O}_{12}\right)\end{array}$ & Diterpenoid & $634.7(\mathrm{M}+\mathrm{Na})$ \\
\hline 29 & 21.16 & 522.63 & 6-acetylneoandrographolide $\left(\mathrm{C}_{28} \mathrm{H}_{42} \mathrm{O}_{9}\right)$ & Diterpenoid & $545.4(\mathrm{M}+\mathrm{Na})$ \\
\hline 30 & 21.95 & 294.38 & $\begin{array}{l}\text { 3,19-dihydroxy-14,15,16-trinor-ent-labda-8(17),11-dien-13-oic } \\
\text { acid }\left(\mathrm{C}_{17} \mathrm{H}_{26} \mathrm{O}_{4}\right)\end{array}$ & Diterpenoid & $311.3(\mathrm{M}+1+\mathrm{O} 2)$ \\
\hline 31 & 22.88 & 334.456 & 14-Deoxyandrographiside $\left(\mathrm{C}_{20} \mathrm{H}_{30} \mathrm{O}_{4}\right)$ & Diterpenoid & $352.3(\mathrm{M}+\mathrm{NH} 4)$ \\
\hline 32 & 24.50 & 511.58 & 3-O- $\beta$-D-Glucopyranosyandrographolide $\left(\mathrm{C}_{26} \mathrm{H}_{39} \mathrm{O}_{10}\right)$ & Diterpenoid & $528.5(\mathrm{M}+1+\mathrm{O} 2)$ \\
\hline 33 & 25.93 & 300.266 & 5,8,2'-Trihydroxy-7-methoxyflavone $\left(\mathrm{C}_{16} \mathrm{H}_{12} \mathrm{O}_{6}\right)$ & Flavone & $601.5(2 \mathrm{M}+1)$ \\
\hline 34 & 26.69 & 352.42 & 7-Hydroxy-14-deoxyandrographolide $\left(\mathrm{C}_{19} \mathrm{H}_{28} \mathrm{O}_{6}\right)$ & Diterpenoid & $354.3(M+2)$ \\
\hline 35 & 27.46 & 330.42 & $\begin{array}{l}\text { 19-hydroxy-3-oxo-ent-labda-8(17),11,13-trien-16,15-olide } \\
\left(\mathrm{C}_{20} \mathrm{H}_{26} \mathrm{O}_{4}\right)\end{array}$ & Diterpenoid & $678.5(2 \mathrm{M}+\mathrm{NH} 4)$ \\
\hline \multicolumn{6}{|c|}{ Negative mode (ES-) } \\
\hline 1 & 9.50 & 350.455 & Andrographolide $\left(\mathrm{C}_{20} \mathrm{H}_{30} \mathrm{O}_{5}\right)$ & Diterpenoid & $349.2(M-1)$ \\
\hline 2 & 10.72 & 350.455 & Andrographolide $\left(\mathrm{C}_{20} \mathrm{H}_{30} \mathrm{O}_{5}\right)$ & Diterpenoid & 395.3 (M+formic acid-1) \\
\hline 3 & 11.18 & 496.597 & Andropanoside $\left(\mathrm{C}_{26} \mathrm{H}_{40} \mathrm{O}_{9}\right)$ & Diterpenoid & 541.3 (M+formic acid-1) \\
\hline
\end{tabular}


Table 3 Identification of compounds present in anti-malarial active extract of Andrographis paniculata by LC-MS/MS analysis (Continued)

\begin{tabular}{|c|c|c|c|c|c|}
\hline $\begin{array}{l}\text { Peak } \\
\text { No. }\end{array}$ & $\begin{array}{l}\text { RT } \\
\text { (Min) }\end{array}$ & $\begin{array}{l}\text { Molecular weight } \\
\text { (g/mol) }\end{array}$ & Molecular formula & $\begin{array}{l}\text { Class of identified } \\
\text { compounds }\end{array}$ & $\begin{array}{l}\text { LC-MS (obtained } \\
\text { mass, } m / z \text { ) }\end{array}$ \\
\hline 4 & 11.57 & 494.57 & $\begin{array}{l}\text { 19-[(b-D-Glucopyranosyl)oxy-19-oxo-entlabda-8(17),13-dien-16, } \\
\text { 15-olide }\left(\mathrm{C}_{26} \mathrm{H}_{38} \mathrm{O}_{9}\right)\end{array}$ & Diterpenoid & 539.5 (M+formic acid-1) \\
\hline 5 & 11.82 & 494.57 & $\begin{array}{l}\text { 19-[(b-D-Glucopyranosyl)oxy-19-oxo-entlabda-8(17),13-dien-16, } \\
\text { 15-olide }\left(\mathrm{C}_{26} \mathrm{H}_{38} \mathrm{O}_{9}\right)\end{array}$ & Diterpenoid & $461.2(\mathrm{M}-1-\mathrm{MeOH})$ \\
\hline 6 & 12.36 & 332.44 & 14-Deoxy-11,12-didehydroandrographolide $\left(\mathrm{C}_{20} \mathrm{H}_{28} \mathrm{O}_{4}\right)$ & Diterpenoid & $331.2(M-1)$ \\
\hline 7 & 13.19 & 480.598 & Neoandrographolide $\left(\mathrm{C}_{26} \mathrm{H}_{40} \mathrm{O}_{8}\right)$ & Diterpenoid & 525.3(M+formic acid-1) \\
\hline 8 & 13.33 & 330.42 & $\begin{array}{l}\text { 19-hydroxy-3-oxo-ent-labda-8(17),11,13-trien-16,15-olide } \\
\left(\mathrm{C}_{20} \mathrm{H}_{26} \mathrm{O}_{4}\right)\end{array}$ & Diterpenoid & $329.3(M-1)$ \\
\hline 9 & 13.66 & 522.63 & 6-acetylneoandrographolide $\left(\mathrm{C}_{28} \mathrm{H}_{42} \mathrm{O}_{9}\right)$ & Diterpenoid & $521.3(M-1)$ \\
\hline 10 & 13.87 & 332.44 & 14-Deoxy-11,12-didehydroandrographolide $\left(\mathrm{C}_{20} \mathrm{H}_{28} \mathrm{O}_{4}\right)$ & Diterpenoid & $331.2(M-1)$ \\
\hline 11 & 14.08 & 318.457 & Andrograpanin $\left(\mathrm{C}_{20} \mathrm{H}_{30} \mathrm{O}_{3}\right)$ & Diterpenoid & 377.3 (M+acetic acid-1) \\
\hline 12 & 14.39 & 334.456 & 14-Deoxyandrographolide $\left(\mathrm{C}_{20} \mathrm{H}_{30} \mathrm{O}_{4}\right)$ & Diterpenoid & $369.1(\mathrm{M}+\mathrm{Cl})$ \\
\hline 13 & 14.39 & 532.586 & 3-Oxo-14-deoxy-11,12-Didehydroandrographolide $\left(\mathrm{C}_{28} \mathrm{H}_{36} \mathrm{O}_{10}\right)$ & Diterpenoid & $567.3(\mathrm{M}+\mathrm{Cl})$ \\
\hline 14 & 15.32 & 664.88 & Bisandrographolide $\mathrm{A}\left(\mathrm{C}_{40} \mathrm{H}_{56} \mathrm{O}_{8}\right)$ & Diterpenoid & $663.5(M-1)$ \\
\hline 15 & 16.52 & 512.596 & Andrographiside $\left(\mathrm{C}_{26} \mathrm{H}_{40} \mathrm{O}_{10}\right)$ & Diterpenoid & 557.2 ( M+formic acid-1) \\
\hline 16 & 17.35 & 294.38 & $\begin{array}{l}\text { 3,19-dihydroxy-14,15,16-trinor-ent-labda-8(17), 11-dien-13-oic } \\
\text { acid }\left(\mathrm{C}_{17} \mathrm{H}_{26} \mathrm{O}_{4}\right)\end{array}$ & Diterpenoid & $293.3(M-1)$ \\
\hline 17 & 18.20 & 294.38 & $\begin{array}{l}\text { 3,19-dihydroxy-14,15,16-trinor-ent-labda-8(17), 11-dien-13-oic } \\
\text { acid }\left(\mathrm{C}_{17} \mathrm{H}_{26} \mathrm{O}_{4}\right)\end{array}$ & Diterpenoid & $293.3(M-1)$ \\
\hline 18 & 18.56 & 294.38 & $\begin{array}{l}\text { 3,19-dihydroxy-14,15,16-trinor-ent-labda-8(17),11-dien-13-oic } \\
\text { acid }\left(\mathrm{C}_{17} \mathrm{H}_{26} \mathrm{O}_{4}\right)\end{array}$ & Diterpenoid & 339.3 (M+formic acid-1) \\
\hline 19 & 21.60 & 296.41 & Andrographolactone $\left(\mathrm{C}_{20} \mathrm{H}_{24} \mathrm{O}_{2}\right)$ & Diterpenoid & $295.2(M-1)$ \\
\hline 20 & 24.55 & 334.456 & 14-Deoxyandrographolide $\left(\mathrm{C}_{20} \mathrm{H}_{30} \mathrm{O}_{4}\right)$ & Diterpenoid & $311.3(\mathrm{M}-\mathrm{Na})$ \\
\hline 21 & 26.99 & 454.563 & 19-Benzyl isoandrographolide $\left(\mathrm{C}_{27} \mathrm{H}_{34} \mathrm{O}_{6}\right)$ & Diterpenoid & $453.5(M-1)$ \\
\hline 22 & 27.20 & 454.563 & 19-Benzyl isoandrographolide $\left(\mathrm{C}_{27} \mathrm{H}_{34} \mathrm{O}_{6}\right)$ & Diterpenoid & $453.4(M-1)$ \\
\hline 23 & 30.77 & 368.46 & 12S-Hydroxyandrographolide $\left(\mathrm{C}_{20} \mathrm{H}_{32} \mathrm{O}_{6} \mathrm{Na}\right)$ & Diterpenoid & $367.1(M-1)$ \\
\hline 24 & 31.14 & 294.38 & $\begin{array}{l}\text { 3,19-dihydroxy-14,15,16-trinor-ent-labda-8(17), 11-dien-13-oic } \\
\text { acid }\left(\mathrm{C}_{17} \mathrm{H}_{26} \mathrm{O}_{4}\right)\end{array}$ & Diterpenoid & $293.1(M-1)$ \\
\hline
\end{tabular}

Andrographolide was detected at $m / z 351,[\mathrm{M}+\mathrm{H}]^{+}$ ion (Fig. 7). Its MS/MS spectrum displayed product ions at $187 \mathrm{~m} / z$ as $\mathrm{C}_{10} \mathrm{H}_{12} \mathrm{O}_{2}$ molecule was lost. The product ions at $187 \mathrm{~m} / z$ further yielded ions at 169 and $133 \mathrm{~m} / z$ due to $\mathrm{H}_{2} \mathrm{O}$ and $2 \mathrm{H}_{2} \mathrm{O}$ loss, respectively, a hydrolysis reaction. Loss of $\mathrm{CH}_{2}$ (demethylation) (ion at $133 \mathrm{~m} / z$ ) resulted to the ion at $119 \mathrm{~m} / z$. The ion at $119 \mathrm{~m} / z$ consecutively lost $\mathrm{CH}_{2}$ and yielded the ions at 105 and $91 \mathrm{~m} / \mathrm{z}$ in that order.

Neoandrographolide was detected at $m / z 481$, and its fragmentation pathway is shown in Fig. 8. Product ions at $481 \mathrm{~m} / z$ due to loss of $\mathrm{C}_{10} \mathrm{H}_{10} \mathrm{O}_{2}$ resulted into ions at $319 \mathrm{~m} / z$. Product ions at $319 \mathrm{~m} / z$ lost $\mathrm{H}_{2} \mathrm{O}$ (hydrolysis) and formed product ions at $301 \mathrm{~m} / z$ and also lost $\mathrm{HCHO}$ and formed product ions at $289 \mathrm{~m} / \mathrm{z}$. Loss of CO forms the ion at $289 \mathrm{~m} / z$ resulted in the ion at $261 \mathrm{~m} / \mathrm{z}$, a reverse Diels-Alder (RDA) reaction $[25,26]$. The product ions at $261 \mathrm{~m} / z$ further yielded ions at 231, 205, and $191 \mathrm{~m} / z$ due to loss of $\mathrm{HCHO}, \mathrm{C}_{2} \mathrm{H}_{2}$, and $\mathrm{CH}_{2}$ (demethylation) in that order. Further loss of $\mathrm{CH}_{10} \mathrm{O}$ and $\mathrm{H}_{2} \mathrm{O}$ (hydrolysis) from 191 and $153 \mathrm{~m} / \mathrm{z}$ produced the ions at 153 and $135 \mathrm{~m} / z$ in that order. Consecutive losses of $\mathrm{C}_{2} \mathrm{H}_{2}$ and $\mathrm{CH}_{2}$ (demethylation) were observed from the ion at 135 and $109 \mathrm{~m} / z$ to yield the ions at 109 and $95 \mathrm{~m} / z$. Further, the product ions at 95 and $81 \mathrm{~m} / z$ were observed due to losses of $\mathrm{CH}_{2}$ (demethylation) and $\mathrm{C}_{2} \mathrm{H}_{2}$ to yield the resulted ions at 81 and $55 \mathrm{~m} / \mathrm{z}$.

The fragmentation pathway of bisandrographolide $\mathrm{A}$, detected at $665 \mathrm{~m} / z[\mathrm{M}+\mathrm{H}]{ }^{+}{ }^{+}$ion, is shown in Fig. 9. MS/MS product ion at $665 \mathrm{~m} / z$ due to loss of $\mathrm{C}_{20} \mathrm{H}_{30} \mathrm{O}_{5}$ resulted into ions at $315 \mathrm{~m} / z$. Further, product ions at $315 \mathrm{~m} / z$ due to loss of $\mathrm{H}_{2} \mathrm{O}$ (hydrolysis) and $\mathrm{HCHO}$ produced the ions at 297 and $285 \mathrm{~m} / z$ in that order. The product ions at $285 \mathrm{~m} / z$ due to loss of CO formed product ions at $257 \mathrm{~m} / z$, a reverse Diels-Alder (RDA) reaction $[25,26]$. Loss of $\mathrm{CH}_{4}$ and $\mathrm{CH}_{2}$ (demethylation) respectively from 257 and $241 \mathrm{~m} / z$ resulted in the ions at 241 and $227 \mathrm{~m} / z$. The ions at 203 and $177 \mathrm{~m} / z$ arose by 


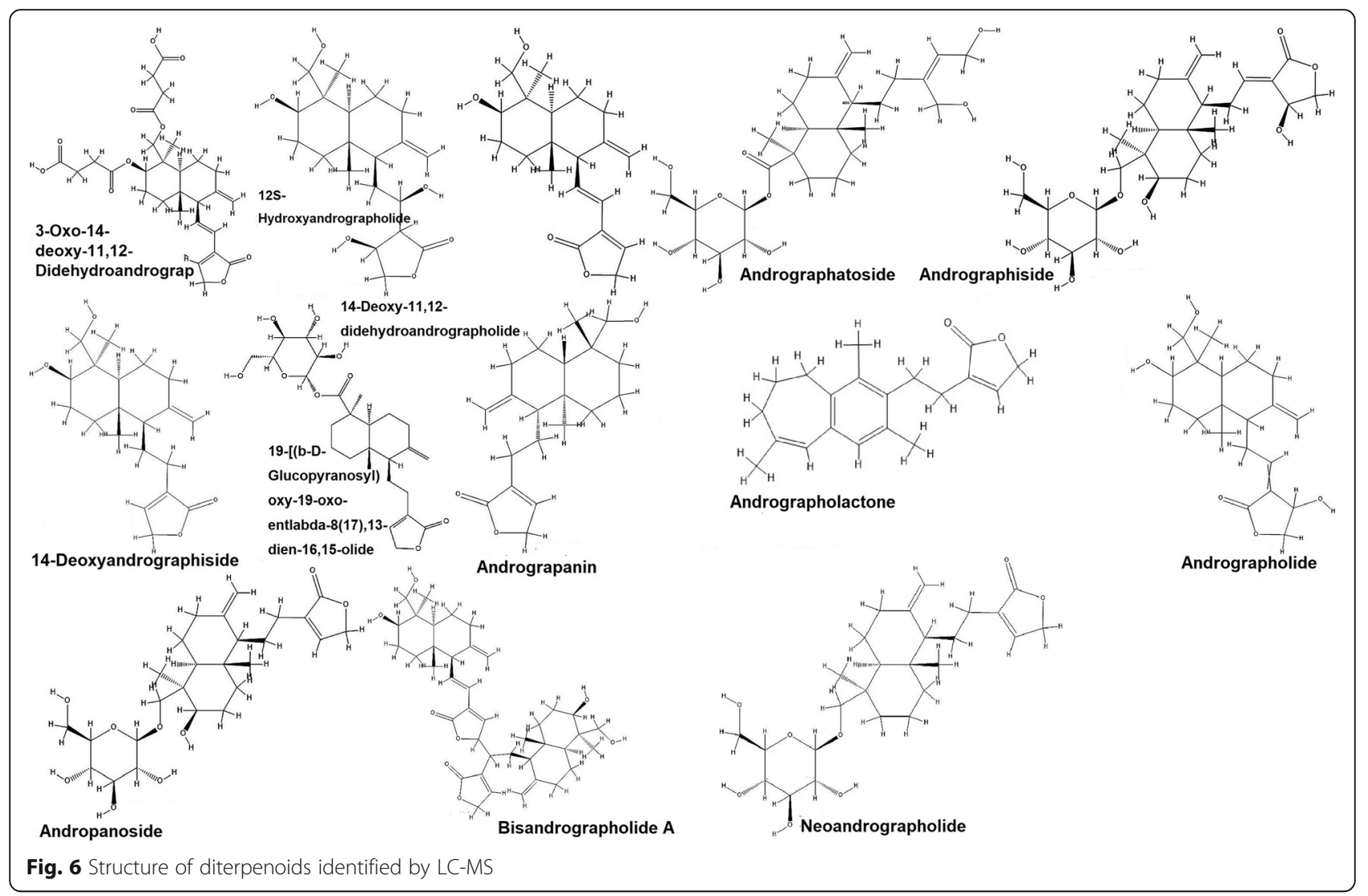

losses of $\mathrm{C}_{2} \mathrm{H}$ and $\mathrm{C}_{2} \mathrm{H}_{2}$ from 227 and $203 \mathrm{~m} / z$ in that order. The ion at $177 \mathrm{~m} / z$ due to loss of $\mathrm{C}_{3} \mathrm{H}_{8}$ yielded the ion at $133 \mathrm{~m} / z$ and $133 \mathrm{~m} / z$, further loss of $\mathrm{C}_{2} \mathrm{H}$ resulted in the ion at $109 \mathrm{~m} / z$. Loss of $\mathrm{CH}_{2}$ (demethylation) from 109 and $95 \mathrm{~m} / z$ in that order, produced the ions at 95 and $81 \mathrm{~m} / \mathrm{z}$.

\section{Discussion}

The current study was undertaken to authenticate the traditional medicinal knowledge of the tribal communities of the Anuppur district, Madhya Pradesh, India. Traditional medicinal systems around the world rely mostly on the medicinal plants prevalent in particular regions of the world. The treatment of various diseases using plant products is possible due to large structural diversity of the secondary metabolites. Most of the modern drugs are isolated from plants or are synthesized based on plant metabolites.

The current study was undertaken with an aim to systematically validate the anti-malarial properties of Indian traditional medicinal plant $A$. paniculata that is known to have potential use in traditional medicine against malaria [27, 28]. However, the phytochemical constituents and the biological activity of these plants vary based on the chemotype under study, collection, and preparation methods. Mishra et al. (2011) has reported anti-malarial activity of methanol extracts of $A$. paniculata with an $\mathrm{IC}_{50}$ value of $9 \mu \mathrm{g} / \mathrm{ml}$. Further, in vitro activity of $A$. paniculata in combination with Hedyotis corymbosa and curcumin has synergistic anti-malarial activity [29]. Several bioactive molecules such as 14deoxyandrographolide, isoandrographolide, neoandrographolide, andrograpanin, andrographolide, andrographic acid, and andrographiside are known to be present in the leaf extract of A. paniculata [30]. In vitro activity ( $\mathrm{IC}_{50}$ value) of andrographolide, isolated from methanol extract of $A$. paniculata, was found to be $9.1 \mu \mathrm{M}$ [29]. Besides anti-malarial activity, A. paniculata plant extracts are traditionally used for treating colic pain, appetite loss, common cold, hypertension, diabetes, cancer, snakebite, liver disorders, anti-pyretic, and antidiarrheal properties. It is being used in at least 26 ayurvedic formulations in Indian Pharmacopeia [31, 32]. Identification of the pure compounds from this extract may open a venue for scientific exploration of new scaffolds against diseases.

TLC is widely used in separation techniques due to its ease of use, low cost, high sensitivity, and quick separation of a large number of samples simultaneously. On the basis of Rf values, we observed three compounds namely 4-deoxy-11, 12-didehydroandrographolide (0.84), andrographolide (0.72), and other flavonoids and 


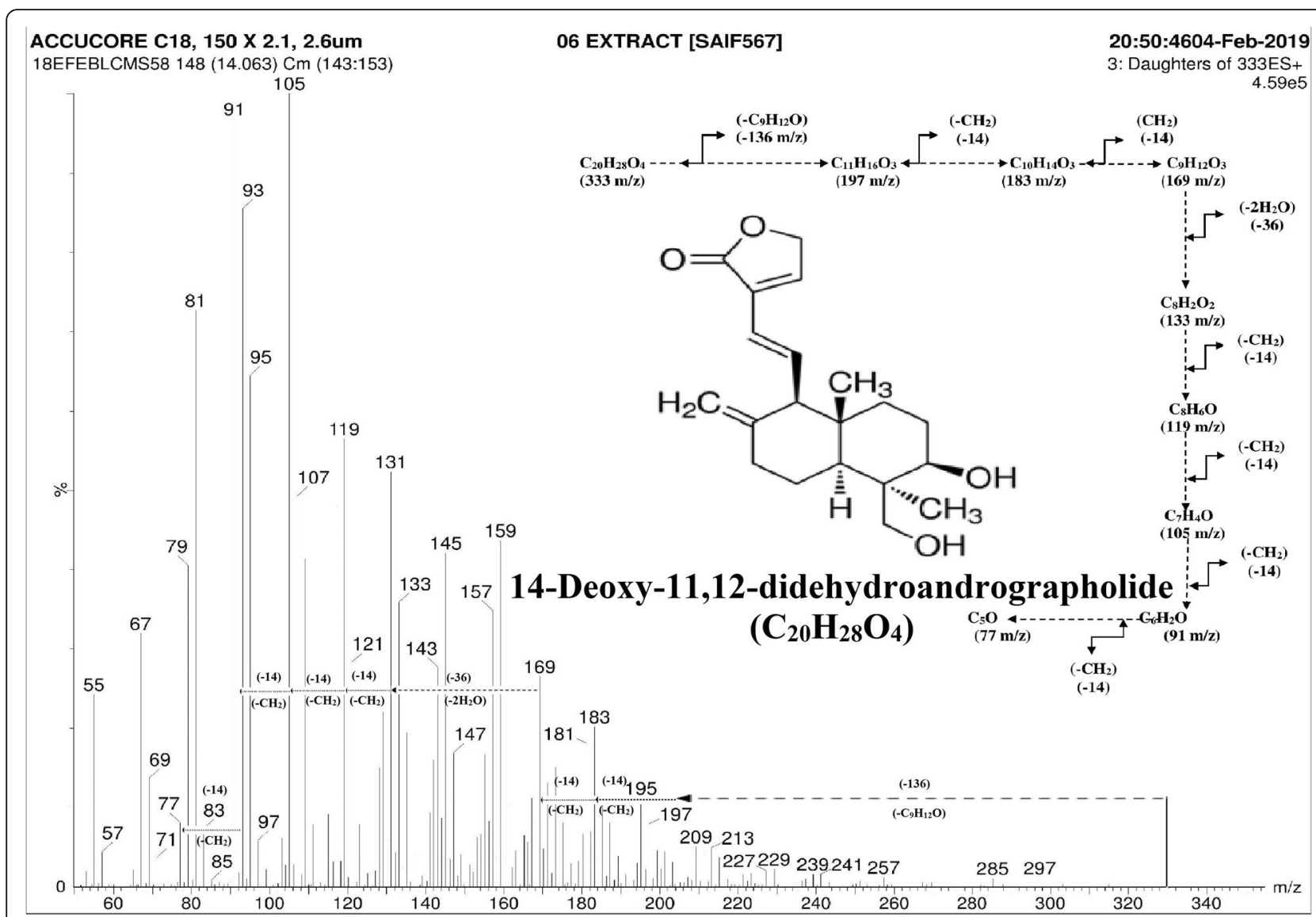

Fig. 7 Fragmentation pathway of 14-deoxy-11, 12-didehydroandrographolide

glycosides $(0.78)$ in the IGNTU_06 extract [33, 34]. The UV-Visible spectrum was compared with reported literature, and we observed a peak at $235 \mathrm{~nm}$ which has been reported to be associated with andrographolide [33, 34]. The spectroscopic analysis also revealed the presence of phenolic and flavonoid compounds in the extract that is an indicator of the medicinal properties of $A$. paniculata. The spectra of phenolics and flavonoids are typically observed between 230 and $290 \mathrm{~nm}$ [35], and within 300$350 \mathrm{~nm}$ [36]. The results confirm the presence of diterpenoids, phenolic, flavonoids and their derivatives in IGNTU_06. Analysis of functional groups gives us a direct idea about the chemical properties of a given compound. Upon FTIR analysis we obtained bands at $1033.4677 \mathrm{~cm}^{-1}$ and $828.7537 \mathrm{~cm}^{-1}$ that revealed that the $\mathrm{C}-\mathrm{N}-$ stretch and $-\mathrm{C}-\mathrm{H}-$ were out of plane, respectively, leading to the idea that the functional groups were amines $\left(\mathrm{RNH}_{2}\right)$ and aromatic $(\mathrm{C}-\mathrm{C}$ ring) respectively. We also report that the functional group at $1376.2922 \mathrm{~cm}^{-1}$ to be $-\mathrm{CH} 3-$ which is a signature of the presence of alkanes with weak intensity. Based on the FTIR spectrum, the results confirm the presence of hydroxyl, aromatic, alkanes, esters, amines, ethers, aromatic nitro, and phosphine compounds in the IGNTU_
06 extract. Presence of hydroxyl group $(-\mathrm{OH})$ indicates the presence of flavonoids, alcoholic, and phenolic compounds thus supporting the UV-VIS spectrum data obtained for the extract. The aromatic properties of $A$. paniculata were confirmed by the presence of aromatic and oxidized nitrogen functional groups. The presence of alkanes, primary and secondary amines, and aromatic compounds confirms the occurrence of alkaloids in the IGNTU_06 extract of the plant. Previous studies have confirmed the presence of hydroxyl, aromatic, alkanes, esters, amines, ethers, aromatic nitro, phenolic, and phosphine groups in A. paniculata plant fresh leaves extracts $[11,37]$.

Based on the reported literature, the two major peaks obtained in the HPLC chromatogram were identified as those belonging to andrographolide and neoandrographolide. We were unable to identify the other six peaks which might be novel compounds not reported earlier. Andrographolide has been reported with RT 4.8 at 223 $\mathrm{nm}$ and RT 5.674 at $223 \mathrm{~nm}$ [38-40]. Neoandrographolide has been reported at RT 14.10 at $220 \mathrm{~nm}$ [41]. Chromatographic and spectral fingerprint analysis plays a significant role in the identification of known and unknown compounds in plant extracts. HPLC generate an 


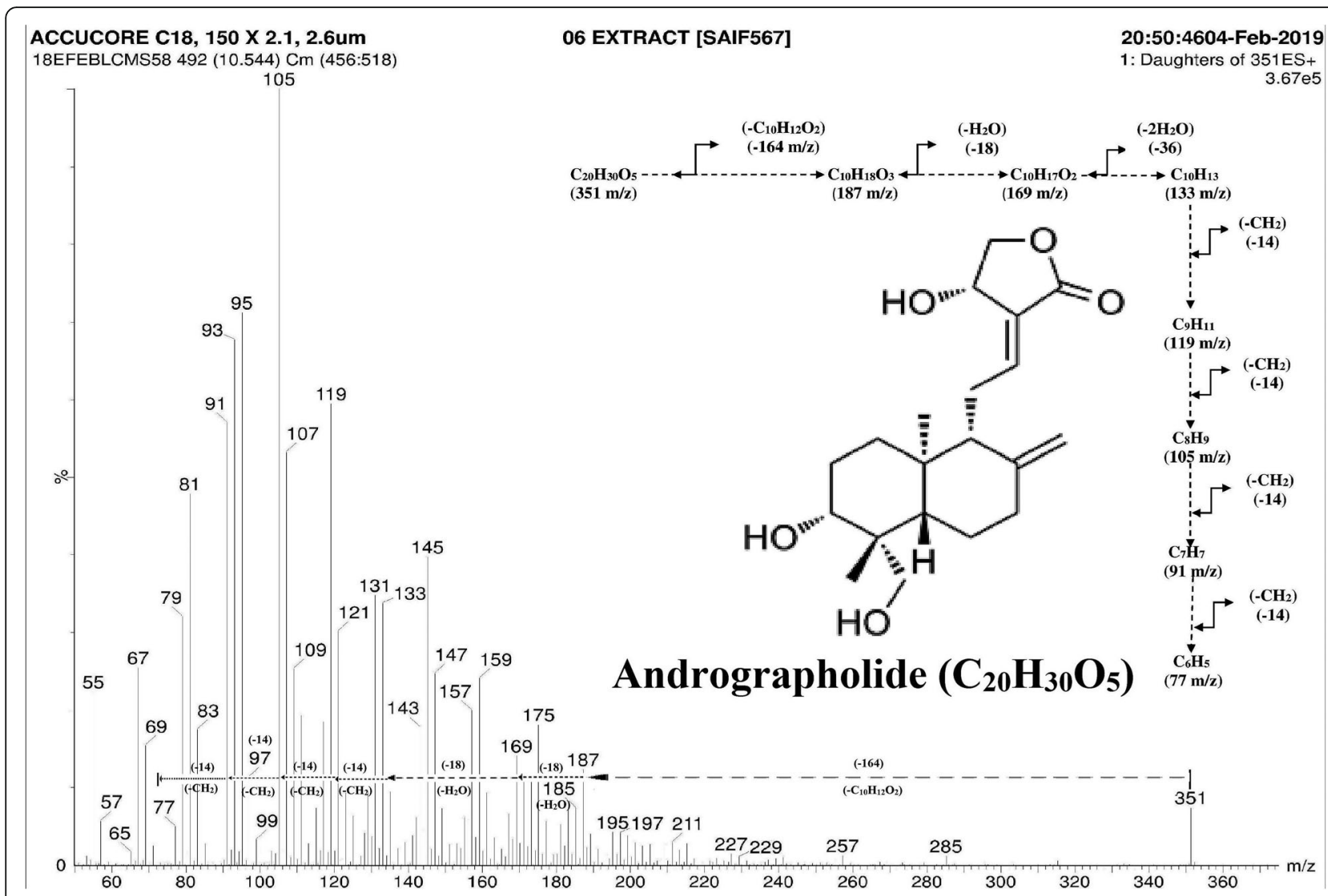

Fig. 8 Fragmentation pathway of Andrographolide

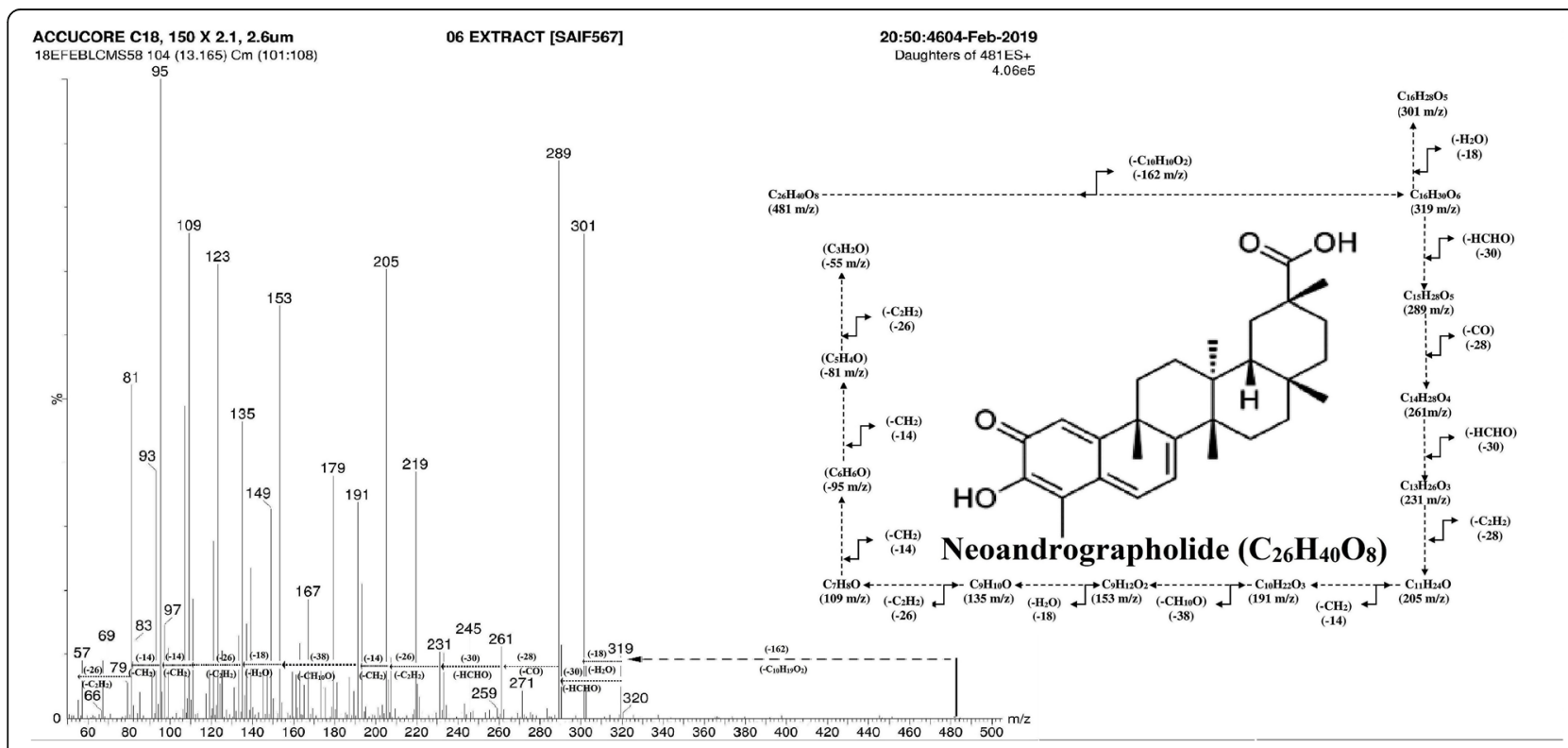

Fig. 9 Fragmentation pathway of Neoandrographolide 
electronic image of the chromatographic fingerprint and a densitogram that is useful for the detection of secondary metabolites in plant samples. However, the fingerprint may vary based on the chemotype of the plant and the experimental conditions utilized. The presence of plant secondary metabolites closely depends upon the geographical location of the plant that has a direct effect on the biological activities of the plant extracts. It therefore becomes to collect the plant as a specific duration of time, select appropriate solvent for extract preparation that might least influence the properties of the secondary metabolites. Some of the identified compounds such as andrographolide have recently received increased attention due to their wide range of medicinal effects such as immunostimulating, anti-cancer, anti-bacterial, anti-inflammatory, anti-viral, anti-angiogenic, anti-HIV, cardio-protective, anti-feedant, and anti-diabetic activities [42, 43]. Neoandrographolide is known to have hypolipidemic, anti-inflammatory, and anti-oxidant effects; it protects the cardiovascular without significant liver damage and has been used as chemosensitizer [44].

In the LC-MS analysis, we were able to identify several diterpenoids in the IGNTU_06 extract in both ion modes $(+\mathrm{V}$ and $-\mathrm{V})$. Diterpenoids are a heterogeneous class of natural compounds, occurring in many medicinal plants [45]. Natural products with medicinal activities can be directly isolated from plants and used in therapies or can act as a basic structure for the development of several derivatives for the development of more active and less toxic analogs [45]. Several diterpenoids including 14-deoxy-11, 12-di-dehydroandrographide, andrographolide, neoandrographolide, and isoandrographolide have been earlier reported from $A$. paniculata [12, 46-48]. Kumar et al. (2018) have reported Skullcapflavone I, 5-Hydroxy-7,8,2',5' -tetraMethoxyflavone 5-O-glucoside and 7-O-Methylwogonin to be present in the methanolic extract of aerial parts of A. paniculata.

Several flavonoids were also identified in the extract analyzed that supports the traditional use of $A$. paniculata in traditional medicine. Flavonoids are known to have a variety of biochemical effects and are antioxidant properties that have been associated with several diseases such as atherosclerosis, cancer, and Alzheimer's [49-51]. Functional hydroxyl groups in flavonoids are known to scavenge free radicals, exert antiinflammatory, and anti-mutagenic properties [52, 53]. They are reported to inhibit several enzymes such as cyclooxygenase, xanthine oxidase, lipoxygenase, and phosphoinositide3-kinase [54-56].

LC-MS/MS-based quantification and structural characterization of the secondary metabolites is the most efficient way for the analysis of plant extracts (Fig. 10). In the current analysis, we utilized both ion modes $(+\mathrm{V}$ and $-\mathrm{V}$ ) for the identification of possible molecules present in the IGNTU_06 extract of A. paniculata. The diterpenoids were identified as monomers or polymers of diterpenoids lactones. Monomers have multiple hydroxyl groups in their structures which release one or two $\mathrm{H}_{2} \mathrm{O}$ molecules upon fragmentation $[57,58]$ which was observed in our fragmentation analysis. Several biological activities have been attributed to diterpenoids

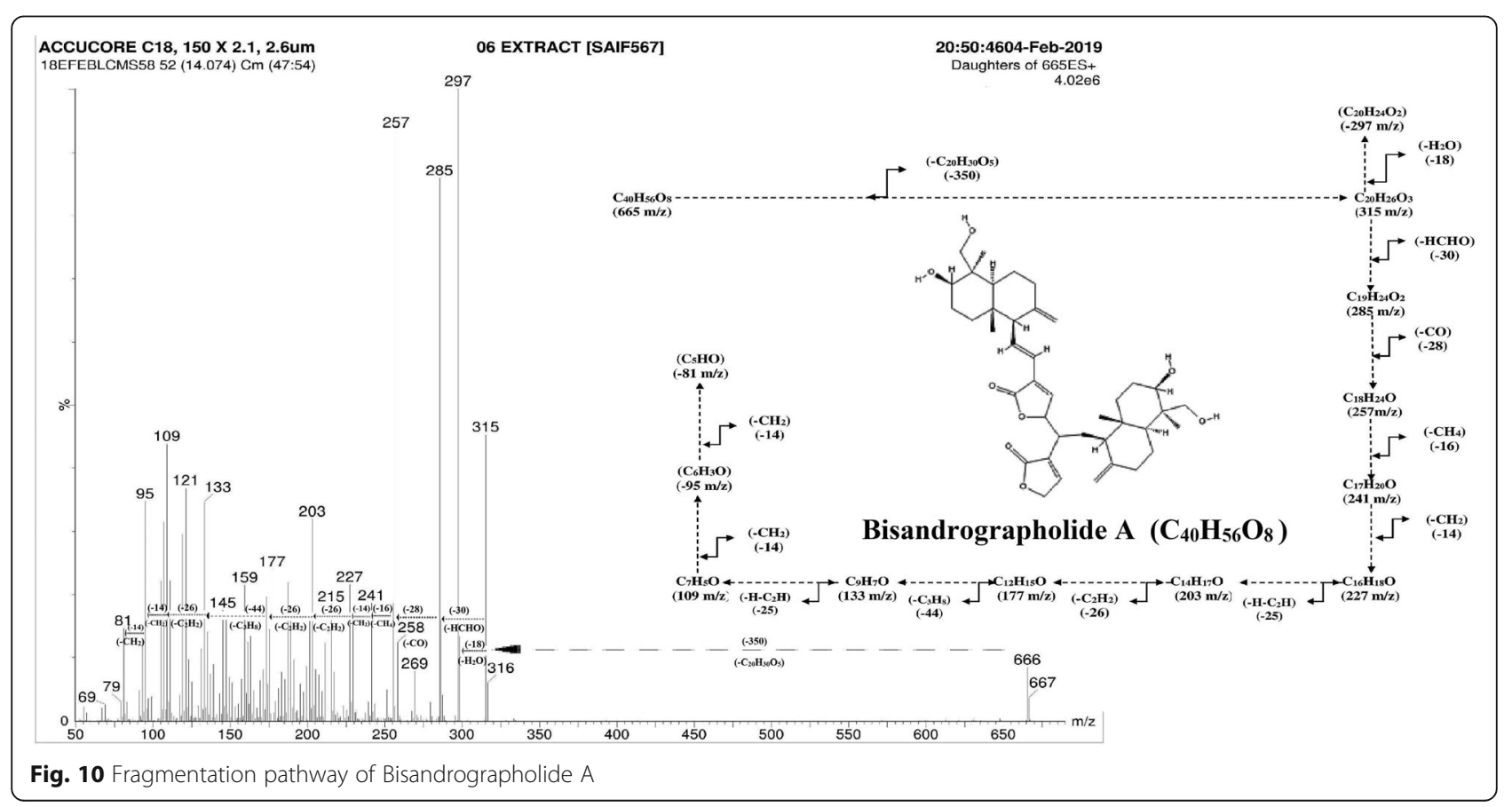


due to their varied distribution [45]. A number of diterpenoids isolated from higher plants have been reported to possess an effect on insect growth regulation [59], insect anti-feedant [60], or insecticidal activity [61], insect pheromones. or defense chemicals [62]. The defensive roles of diterpenoids suggest that the compounds of this class might bear potent anti-malarial activities as compounds from this group were present in maximum number in IGNTU_06 extract. This is also validated by the fact that most of the traditional healers use this plant for the treatment of malaria in the study area.

\section{Conclusions}

We report a total of 59 compounds to be present in the IGNTU_06 extract. Most of the metabolites identified based on the LC-MS analysis belonged to the diterpenoids class of the compounds that were definite by LCMS/MS analysis. The results present us with enormous structural and chemical diversity of natural products that can be utilized for anti-malaria drug development programs. This is to also mention that the LC-MS method developed by us can be uniquely used for the identification of maximum diterpenoids from $A$. paniculata as we obtained 54 diterpenoids from the 59 compounds evaluated. The results strongly validate the traditional use of A. paniculata by the traditional healers of the Amarkantak region. Activity-guided fractionization, purification, and characterization of the active components of the $A$. Paniculata extract are underway.

\section{Acknowledgements}

The authors are grateful to the Indian Council of Medical Research -DHR for providing the funding to MKD in the form of Young Scientist Scheme. We also thank Mr. Ashan Manhas and Dr. Niti Kumar, anti-malarial screening facility, CSIR-Central Drug Research Institute, Lucknow, India, for carrying out the anti-malarial assays. The authors would also like to thank SAIF, CSIR-Central Drug Research Institute, Lucknow, Uttar Pradesh, India, for LC-MS/MS analysis.

\section{Authors' contributions}

MKD, SS, and SM collected the plant material, performed the experiments, analyzed the data, and wrote the manuscript. PKS designed the study, analyzed the data, and wrote the manuscript. All authors read and approved the final manuscript.

\section{Funding}

ICMR-DHR, New Delhi. The funder has no role in the design of the study and collection, analysis, and interpretation of data and in writing the manuscript.

\section{Availability of data and materials}

All data generated or analyzed during this study are included in this published article.

Ethics approval and consent to participate

Human Ethics Committee clearance number for the $P$. falciparum culture in human RBCs is CDRI/IEC/2019/A8.

\section{Consent for publication}

Not applicable

\section{Competing interests}

The authors declare that they have no competing interests.
Received: 16 September 2020 Accepted: 8 January 2021

Published online: 23 January 2021

\section{References}

1. Nguta JM, Mbaria JM, Gakuya DW, Gathumbi PK, Kiama SG (2010) Antimalarial herbal remedies of Msambweni, Kenya. J. Ethnopharmacol. 128: 424-432

2. Wadi I, Prasad D, Batra N, Srivastava K, Anupkumar R Anvikar, Valecha N (2018) Targeting asexual and sexual blood stages of human malaria parasite P. falciparum with 7-chloroquinoline based $[1,2,3]$ - triazoles. ChemMedChem. https://doi.org/https://doi.org/10.1002/cmdc.201800728.

3. Imwong M, Suwannasin K, Kunasol C, Sutawong K, Mayxay M, Rekol H, Smithuis FM, Hlaing TM, Tun KM, Van der Pluijm RW, Tripura R, Miotto O, Menard D, Dhorda M, Day NPJ, White NJ (2017) The spread of artemisininresistant Plasmodium falciparum in the Greater Mekong subregion: a molecular epidemiology observational study. Lancet Infect Dis. 17:491-497. https://doi.org/doi. https://doi.org/10.1016/S1473-3099(17)30048-8

4. Yusuf OB, Adeoye BW, Oladepo OO, Peters DH, Bishai D (2010) Poverty and fever vulnerability in Nigeria: a multilevel analysis. Malar. J 9:1-6

5. Bickii J, Njifulie N, Foyere JA, Basco LK, Ringwald P (2000) In vitro antimalarial activity of limonoids from Khaya grandifoliola C.D.C. (Meliaceae). J. Ethnopharmacol. 69:27-33

6. Fabricant DS, Farnsworth NR (2001) The value of plants used in traditional medicine for drug discovery. Environ. Health Perspect. 109:69-75

7. Ovais S, Sayeed A, Shahid U (2014) Andrographis paniculata: a critical appraisal of extraction, isolation and quantification of andrographolide and other active constituents. Natural Product Research, 28,2081-2101.http://dx. doi.org/https://doi.org/10.1080/14786419.2014.924004.

8. Massimo M (2003) Dietary supplements of plant originnutrition and health approach, Taylor \& Francis Ltd. New York, Chapter 3:26-29

9. Dwivedi MK, Shyam BS, Lal M, Singh PK, Sharma NK (2019) Geospatial mapping of antimalarial plants used by the ethnic groups of Anuppur district ( Madhya Pradesh, India ). Indian J. Tradit. Knowl. 18:261-271

10. Dwivedi MK, Shyam BS, Shukla R, Sharma NK, Singh PK (2020) GIS mapping of antimalarial plants based on traditional knowledge in Pushparajgarh Division, District Anuppur, Madhya Pradesh, India. J. Herbs, Spices Med Plants 00, 1-23. https://doi.org/https://doi.org/10.1080/10496475.2020. 1747583.

11. Baby VS, Sriman NJ (2015) Characterization studies on medicinal plant of Andrographis paniculata (NEES). Journal of Medicinal Plants Studies 3(5):96102

12. Chao WW, Lin BF (2010) Isolation and identification of bioactive compounds in Andrographis paniculata (Chuanxinlian). Chao and Lin Chinese Medicine 5:17. 10.

13. Sareer O, Ahad A, Umar S (2012) Prophylactic and lenitive effects of Andrographis paniculata against common human ailments: an exhaustive and comprehensive reappraisal. J Pharm Res Opin. 2:138-162

14. Li JWH, Vederas JC (2009) Drug discovery and natural products: end of an era or an endless frontier? Science 325:161-165

15. Joselin J, Jeeva S (2014) Andrographis paniculata: a review of its traditional uses, phytochemistry and pharmacology. Med Aromat Plants 3:4. https://doi. org/10.4172/2167-0412.1000169

16. Radhika P, Prasad YR, Lakshmi KR (2010) Flavones from the stem of Andrographis paniculata Nees. Nat Prod Commun 5(1):59-60

17. Rajagopal S, Kumar RA, Deevi DS, Satyanarayana C, Rajagopalan R (2003) Andrographolide, a potential cancer therapeutic agent isolated from Andrographis paniculata. J. Exp. Ther.Oncol. 3:147-158

18. Singha PK, Roy S, Dey S (2003) Antimicrobial activity of Andrographis paniculata. Fitoterapia. 74:692-694

19. Jarukamjorn K, Nemoto N (2008) Pharmacological aspects of Andrographis paniculata on health and its major diterpenoid constituent andrographolide. J Health Sci 54:370-380

20. Akbar S (2011) Andrographis paniculata: a review of pharmacological activities and clinical effects. Altern Med Rev 16:66-77

21. Buckingham J (2011) Dictionary of natural products on DVD. Chapman and Hall/ CRC, Version 19:1, London, UK.

22. Trager W, Jensen JB (1976) Human malaria parasites in continuous culture Science 193(4254):673-675

23. Srivastava K, Puri SK (2004) Plasmodium falciparum: modified medium composition supports continuous cultivation with foetal bovine serum. Exp. 
Parasitol. 108, 74-75. https://doi.org/https://doi.org/10.1016/j.exppara.2004. 07.008.

24. Smilkstein M, Sriwilaijaroen N, Kelly JX, Wilairat P, Riscoe M (2004) Simple and inexpensive fluorescence-based technique for high-throughput antimalarial drug screening. Antimicrob. Agents Chemother 48:1803-1806

25. Wu W, Yan C, Li L, Liu Z, Liu S (2004) Studies on the flavones using liquid chromatography-electrospray ionization tandem mass spectrometry. J. Chromatogr. A 1047:213-220

26. Fabre N, Rustan I, de Hoffmann E, Quetin-Leclercq J (2001) Determination of flavone, flavonol, and flavanone aglycones by negative ion liquid chromatography electrospray ion trap mass spectrometry. J. Am. Soc. Mass Spectrom. 12:707-715

27. Waltera NS, Bagai U (2015) Antimalarial efficacy of Thalictrum foliolosum (Meadow rue) against chloroquine -resistant P. falciparum. J Trop Dis Pub Heal. 3, 1000163.

28. Banyal HS (2015) Antimalarial effect of Ocimum sanctum Linn and Bauhinia variegate Linn, on Plasmodium berghei. IOSR-J PharmBiol Sci. 10:70-72

29. Mishra K, Dash AP, Dey N (2011) Andrographolide: a novel antimalarial diterpene lactone compound from andrographis paniculata and its interaction with curcumin and artesunate. J Trop Med. 579518

30. Panossian A, Davtyan T, Gukassyan N, Gukasova G, Mamikonyan G, Gabrielian E (2002) Effect of andrographolide and Kan Jang fixed combination of extract SHA-10 and extract SHE-3 on proliferation of human lymphocytes, production of cytokines and immune activation markers in blood cell culture. Phytomedicine 9:598-605

31. Sareer O, Ahmad S, Umar S (2014) Andrographis paniculata: a critical appraisal of extraction, isolation and quantification of andrographolide and other active constituents. Nat. Prod. Res. 28, 2081-2101. https://doi.org/ https://doi.org/10.1080/14786419.2014.924004

32. Agbonlahor O, Joyce EF, Osayemwenre E, Vincent I, Abiodun Falodun PL (2014) Harnessing the medicinal properties of Andrographis paniculata for diseases and beyond: a review of its phytochemistry and pharmacology. Asian Pac J Trop Dis. 4:213-222

33. Bhusnure OG, Pangave VS, Gholve SB, Giram PS, Attar MS (2018) Qualitative phytochemical screening and development of high-performance thin layer chromatography fingerprint profile of Andrographis paniculata (Leaf). Journal of Pharmacy Research 12(5):743-748

34. Raghavan R (2014) In vitro activities of andrographolide and its derivative on cell lines Thesis. Department of Biotechnology, University of Calicut.

35. Santhanakrishnan D, Sripriya N, Chandrasekaran B (2014). Studies on the phytochemistry, spectroscopic characterization and antibacterial efficacy of Salicornia brachiata. International Journal of Pharmacy and Pharmaceutical Sciences. 6. 430-432.

36. Rajesh Kumar R, Jeyaprakash K (2016) Screening of UV-VIS, TLC and FTIR spectroscopic studies on selected red seaweed (Acanthophora specifera) collected from Gulf of Mannar, Tamilnadu, India. World J Pharm Sci 4(10): 28-33

37. Sajeeb BK, Kumar U, Halder S, Sitesh CB (2015) Identification and quantification of andrographolide from Andrographis paniculata (Burm. f.) Wall. ex Nees by RP-HPLC Method and Standardization of its Market Preparations. J. Pharm. Sci. 14(1):71-78

38. Sharma S, Sharma YP (2018) Comparison of different extraction methods and HPLC method development for the quantification of andrographolide from Andrographis paniculata (Burm.f.) Wall. ex Nees. Annals of Phytomedicine 7(1): 119-130. doi: 10.21276/ap.2018.7.1.15.

39. Yandi S, Ronny M, Endang L, Agung Endro N (2016) Quantification of andrographolide isolated from Andrographis paniculata Nees obtained from traditional market in Yogyakarta Using Validated HPLC. Indones. J. Chem. 16(2):190-197

40. Rajani M, Shrivastava N, Ravishankara MN (2000) A rapid method for isolation of Andrographolide from Andrographphis paniculata nees (kalmegh). Pharmaceutical Biologol. 38(3):204-209

41. Srivastava A, Misra H, Verma RK, Gupta MM (2004) Chemical fingerprinting of Andrographis paniculata using HPLC, HPTLC and densitometry. Phytochemical analysis. Phytochem. Anal. 15, 280-285. doi: 10.1002.pca.779.

42. Varma A, Padh H, Shrivastava N (2011) Andrographolide: a new plantderived antineoplastic entity on horizon. Evidence-Based Complementary and Alternative Medicine. https://doi.org/10.1093/ecam/nep135

43. Jayakumar T, Cheng-Ying H, Lee JJ, Sheu JR (2013) Experimental and clinical pharmacology of Andrographis paniculata and its major bioactive phytoconstituent andrographolide. Evidence-Based Complementary and
Alternative Medicine 16. http://dx.doi.org/https://doi.org/10.1155/2013/ 846740.

44. Pfisterer PH, Rollinger JM, Schyschka L, Rudy A, Vollmar AM, Stuppner H (2010) Neoandrographolide from Andrographis paniculata as a potential natural chemosensitizer. Planta Med. 76(15):1698-1700. https://doi.org/10. 1055/s-0030-1249876

45. Lanzotti V (2013) Diterpenes for Therapeutic Use. In: Ramawat K, Mérillon JM (eds) Natural Products. Springer, Berlin, Heidelberg

46. Reddy MVB, Kishore PH, Rao CV, Gunasekar D, Caux C, Bodo B (2003) New 2'- oxygenated flavonoids from Andrographis affinis. J Nat Prod 66:295-297

47. Shen YH, Li RT, Xiao WL, Xu G, Lin ZW, Zhao QS, Sun HD (2006) ent-Labdane Diterpenoids from Andrographis paniculata. J. Nat. Prod. 69:319-322

48. Kumar S, Singh A, Bajpai V, Sharma KR, Kumar B (2018) Identification and characterization of terpenoid lactones and flavonoids from ethanolic extract of Andrographis Paniculata (Burm.f.) Nees using liquid chromatography/ tandem mass spectrometry. Sep Sci plus 1:762-770. https://doi.org/10.1002/ sscp.201800106

49. Burak M, Imen Y (1999) Flavonoids and their antioxidant properties. Turkiye Klin Tip Bil Derg19, 296-304.

50. Ovando C, Hernandez D, Hernandez E (2009) Chemical studies of anthocyanins: a review. Food Chem113:859-871

51. Lee Y, Yuk D, Lee J (2009) Epigallocatechin-3-gallate pre-vents lipopolysaccharide-induced elevation of $\beta$-amyloid gener-ation and memory deficiency. Brain Res1. 250, 164-174.

52. Kumar S, Mishra A, Pandey AK (2013) Antioxidant mediated protective effect of Parthenium hysterophorus against oxidative damage using in vitro models. BMC Complementary and Alternative Medicine 13:120

53. Kumar S, Pandey AK (2013) Phenolic content, reducing power and membrane protective activities of Solanum xanthocarpum root extracts. Vegetos 26:301-307

54. Metodiewa D, Kochman A, Karolczak S (1997) Evidence for antiradical and antioxidant properties of four biologically active N, N, diethylaminoethyl ethers of flavanone oximes: a comparison with natural polyphenolic flavonoid (rutin) action. BiochemMol Biol Int. 41:1067-1075

55. Hayashi T, Sawa K, Kawasaki M (1988) Inhibition of cow's milk xanthine oxidase by flavonoids. J Nat Prod. 51:345-348

56. Walker E, Pacold M, Perisic O (2000) Structural determina-tions of phosphoinositide 3-kinase inhibition by wortmannin, LY294002, quercetin, myricetin, and staurosporine. Mol Cell. 6:909-919

57. Ding L, Luo XB, Tang F, Yuan JB, Guo M, Yao SZ (2008) Quality control of medicinal herbs Fructus gardeniae, common andrographis herb and their preparations for their active constituents by high-performance liquid chromatography-photodiode array detection-electrospray mass spectrometry. Talanta 74:1344-1349

58. Yang T, Xu C, Wang ZT, Wang CH (2013) Comparative pharmacokinetic studies of andrographolide and its metabolite of 14-deoxy-12-hydroxyandrographolide in rat by ultra-performance liquid chromatography-mass spectrometry. Biomed. Chromatogr. 27:931-937

59. Fujita E, Nagao Y, Node M, Kaneko K, Nakazawa S, Kuroda H (1976) Antitumor activity of the Isodon diterpenoids: structural requirements for the activity. Experientia 32:203

60. Kubo I, Nakanishi K (1979) Some terpenoid insect antifeedants from tropical plants. Advances in pesticides science. In: Geissbuhler H, Brooks GT, Kearney PC (eds) Pergamon, Oxford, 284.

61. Casida JE (1976) Prospectus for new types of insecticides. In: Metcalf RL, Meckelvey JJ (eds) The future for insecticides. Wiley Interscience, New York, p 349

62. Seo S, Seto H, Koshino H, Yoshida S, Ohashi Y (2003) A diterpene as an endogenous signal for the activation of defense responses to tobacco mosaic virus infection and wounding in tobacco. Plant Cell 15:863

\section{Publisher's Note}

Springer Nature remains neutral with regard to jurisdictional claims in published maps and institutional affiliations. 